\title{
AUTOMAÇÃO DE UMA ALTERNATIVA TECNOLÓGICA CONCEBIDA PARA REALIZAR A LIMPEZA DE TROCADORES DE CALOR POR ESFERAS ABRASIVAS
}

\section{Projeto de Graduação}

Projeto de Graduação apresentado ao Departamento de Engenharia Mecânica da PUC-Rio

Orientador: Carlos Roberto Hall Barbosa Co-orientador: Maurício Nogueira Frota 


\section{AGRADECIMENTOS}

Agradeço a Deus pela força e coragem durante toda esta longa caminhada.

Ao meu orientador Carlos Roberto Hall Barbosa, e ao meu co-orientador Maurício Nogueira Frota pela paciência, disponibilidade e incentivo na orientação que tornaram possível a conclusão deste trabalho.

Aos meus amados pais, Maurício e Perpétua, que com muito carinho e apoio, não mediram esforços para que eu chegasse até esta etapa de minha vida, dedico esta, bem como todas as minhas demais conquistas.

À minha irmã, Carolline, e ao meu namorado, Bruno, pelo incentivo e apoio constante.

Aos meus amigos da PUC por compartilhar todas dificuldades da graduação. 


\title{
RESUMO
}

\author{
Automação de uma alternativa tecnológica concebida para realizar a de limpeza de tro- \\ cadores de calor por esferas abrasivas
}

O presente Projeto Final em Engenharia Mecânica (TCC) desenvolveu-se no âmbito de um projeto de P\&D mais amplo, financiado pelo Programa Light/Aneel de Pesquisa e Desenvolvimento, sob a responsabilidade do Programa de Pós-Graduação em Metrologia da PUC-Rio. Enquanto o projeto de P\&D objetiva automatizar a operação de uma alternativa tecnológica, que faz uso de esferas abrasivas, para viabilizar a limpeza de trocadores de calor utilizados no arrefecimento de hidrogeradores, o TCC concentrou-se no acompanhamento da construção do sistema de automação e realização de testes de funcionalidade em laboratório para verificar se os sinais optoeletrônicos gerados por contadores de esferas são, de fato, capazes de gerenciar o total de esferas introduzidas e recuperadas durante cada ciclo de limpeza. Operando na faixa do infravermelho, esses dispositivos optoeletrônicos constituem-se na inteligência do sistema, que permite controlar um conjunto de eletroválvulas que regulam o fluxo da água de resfriamento nos tubos internos do trocador, assim transportando as esferas abrasivas utilizadas para remover a incrustação que se deposita nas paredes internas dos tubos do trocador. O sistema automatiza a ativação de um novo ciclo de limpeza sempre que o total de esferas inseridas for igual ao total de esferas recuperadas após sua circulação pelo trocador de calor. Testado e validado em ambiente laboratorial, o sistema mostrou-se capaz de gerar os sinais lógicos que comandam as operações da automação, gerando, automaticamente, um log de todas as operações de funcionamento realizadas.

Palavras chaves: Automação, limpeza de trocadores de calor, esferas abrasivas, contadores de esferas. 


\section{ABSTRACT \\ Automation of a technological alternative conceived to perform cleaning of heat exchan- gers by Abrasive spheres}

The present Final Project in Mechanical Engineering was developed under a broader R\&D project, funded by the Light/Aneel Research and Development Program, under the responsibility of the Postgraduate Program in Metrology of PUC-Rio. While the R\&D project aims to automate the operation of a technological alternative, which uses abrasive spheres to enable the cleaning of heat exchangers used in the cooling of hydro generators, this project focused on the monitoring of the construction of the automation system and the functional laboratory tests realization to verify that the optoelectronic signals generated by spheres counters are in fact capable of managing the total of spheres introduced and recovered during each cleaning cycle. Operating in the infra-red zone, these optoelectronic devices constitute the intelligence of the system, that allows to control a set of electrovalves that regulate the flow of the cooling water in the inner tubes of the exchanger, transporting that way the abrasive spheres used to remove the incrustation deposited on the inner walls of the exchanger tubes. The system automates the activation of a new cleaning cycle whenever the total number of spheres inserted is equal to the total number of spheres recovered after their circulation through the heat exchanger. Tested and validated in a laboratorial atmosphere, the system was found able to generate the logic signals that control the automation operations, automatically generating a log of all operations performed.

Key-words: Automation, heat exchanger cleaning, abrasive spheres, spheres counters. 


\section{Conteúdo}

1 Introdução $\quad 6$

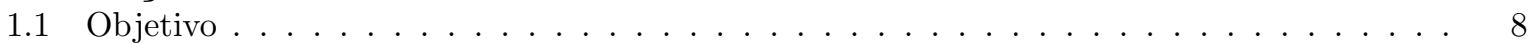

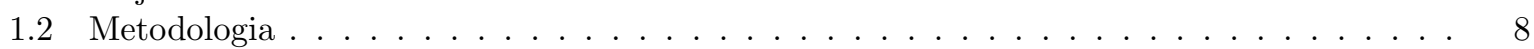

2 Fundamentos Teóricos $\quad 9$

2.1 Trocadores de Calor . . . . . . . . . . . . . . . . . . . . . . . . 9

2.2 Sistemas de Limpeza . . . . . . . . . . . . . . . . . . . . . . . . . . . . . 11

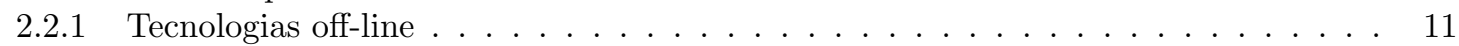

2.2 .2 Tecnologias on-line . . . . . . . . . . . . . . . . . . . . . . 12

2.3 Automação Industrial . . . . . . . . . . . . . . . . . . . . . . . . . . . . . 14

2.3.1 Controladores Lógicos Programáveis . . . . . . . . . . . . . . . . . . . . . 15

2.3.2 Sistema de Supervisão e Aquisição de Dados (SCADA]) . . . . . . . . . . . . . . 18

2.3.3 Interface Homem Máquina $(\mathrm{IHM}) \ldots \ldots \ldots \ldots$

3 Contador de Esferas: Gerador de Sinais para Automação 20

4 Projeto de Automação $\quad 29$

4.1 Programação do CLP . . . . . . . . . . . . . . . . . . . . . . . . . . . . . 30

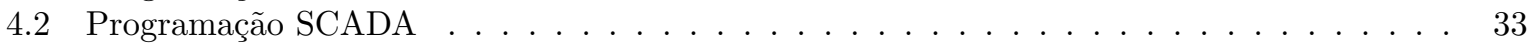

4.3 Comunicação CLP-SCADA . . . . . . . . . . . . . . . . . . . . . 37

5 Testes e Conclusões $\quad 38$

6 Referência Bibliográficas $\quad 39$ 


\section{Lista de Figuras}

1 Reservatório de Lajes, fonte de água de abastecimento da Usina de Fontes Nova. . . . . . 6

2 Esquema de funcionamento de uma hidrelétrica. . . . . . . . . . . . . . . . . 7

3 Fluidos movendo no mesmo sentido, e em sentidos opostos, respectivamente. . . . . . . . . 9

4 Escoamento cruzado: tubos aletados. . . . . . . . . . . . . . . . . . . 9

5 Escoamento cruzado: tubos sem aletas. . . . . . . . . . . . . . . . . . . 10

6 Trocador de calor casco e tubo de um passe. . . . . . . . . . . . . . . . . . . . 10

7 Técnica de limpeza por lavagem (foto da esquerda) e varetagem (à direita). . . . . . . . . 12

8 Passagem de uma escova dentro do trocador de calor . . . . . . . . . . . . . . . . 13

9 Ação da esfera dentro do duto. . . . . . . . . . . . . . . . . . . . . . . . 13

10 Esferas recuperadas após realizada limpeza. . . . . . . . . . . . . . . . . . . . 13

11 Diagrama simplificado de um sistema automático de Controle. . . . . . . . . . . . . . . . 14

12 Estrutura organizacional de um sistema automático de controle. . . . . . . . . . . . . . . 14

13 Variáveis de controle analógicas (a) e digitais (b) . . . . . . . . . . . . . . . . . 15

14 Estrutura básica de um CLP. . . . . . . . . . . . . . . . . . . . . . . . 16

15 CLP usado no projeto de automação do SIREA . . . . . . . . . . . . . . . . . . 16

16 Ciclo de funcionamento do processamento do CLP . . . . . . . . . . . . . . . . . . 18

17 Diagrama elétrico à esquerda e diagrama em Ladder à direita do acionamento de uma lâmpada.

18 Dois CLPs monitorados por um sistema SCADA. . . . . . . . . . . . . . . . . . . . . . 19

19 PC Industrial Advantech. . . . . . . . . . . . . . . . . . . . . . . . . . 20

20 Sensor Honeywell HOA 6299. . . . . . . . . . . . . . . . . . . . . . . . . 20

21 LED SEP8736 e o fototransitor SDP8436. . . . . . . . . . . . . . . . . . . . . 21

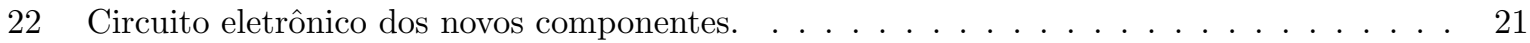

23 Bancada Experimental: sensores-tubo-esfera abrasiva. . . . . . . . . . . . . . . . . 22

24 Concentrações de corantes: 0,25ml/l, 0,75 ml/1, 1,50 ml/l, 2,25 ml/1, 3,0 ml/1 e 6,00 ml/l. 22

25 Queda de tensão do fototransitor devida à adição de corante. . . . . . . . . . . . . . . . 23

26 Esquema de detecção com 2 feixes infravermelhos defasados de 90 graus entre si. (a) Vista frontal. (b) Vista lateral. . . . . . . . . . . . . . . . . . . . . . . . . . . . . 23

27 Princípio de estimativa da velocidade linear das esferas, com base na largura do pulso de

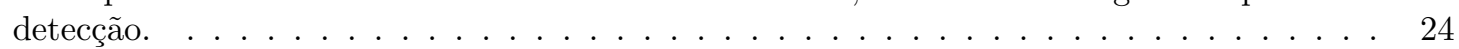

28 Resposta de captura de esferas próxima. . . . . . . . . . . . . . . . . . . . . 24

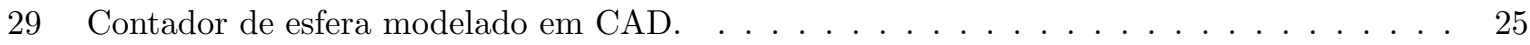

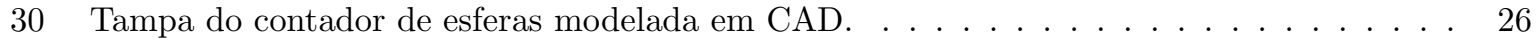

31 Circuito completo com a montagem dos componentes. . . . . . . . . . . . . . . . 26

32 PCB montado no bloco de acrílico. . . . . . . . . . . . . . . . . . . . . . . . 27

33 Parte do conector e pinagem entre PCB e conector. . . . . . . . . . . . . . . . . . 27

34 Vista superior, direita, inferior e isométrica da montam final . . . . . . . . . . . . 28

35 SIREA Versão 2.0 acoplado ao trocador de calor. . . . . . . . . . . . . . . . . . . . . . 29

36 Esquema da nova concepção do SIREA. . . . . . . . . . . . . . . . . . . . . . . . . . . . . . . . . . . . . . . . . . . .

37 Início do processo de injeção. . . . . . . . . . . . . . . . . . . . . . . . . 30

38 Carregamento do número de esferas a serem usadas. . . . . . . . . . . . . . . . . . . 31

39 Verificação do número de esferas disponíveis. . . . . . . . . . . . . . . . . . . . . . 31

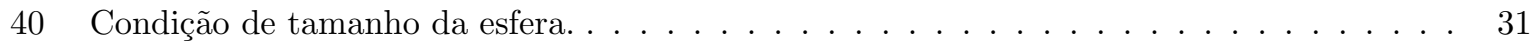

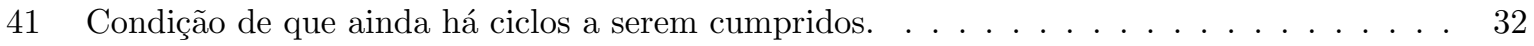

42 Fim do processo de injeção de esferas. . . . . . . . . . . . . . . . . . . . . . . . . . 32

43 Bloco do inversor A/D. . . . . . . . . . . . . . . . . . . . . . . 33

44 Tela de Visão Geral. . . . . . . . . . . . . . . . . . . . . . . . . . . . . . . . 33

45 Tela de identificação dos trocadores de calor. . . . . . . . . . . . . . . . . . . . . 34

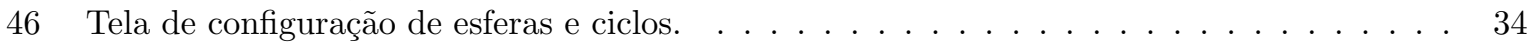

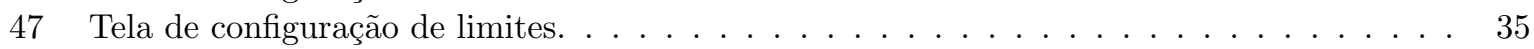

48 Tela de Reconhecimento de alarmes. . . . . . . . . . . . . . . . . . . . . . . . . 36

49 Gráficos do comportamento. . . . . . . . . . . . . . . . . . . . 36 


\section{Introdução}

O uso da "força das águas" para gerar energia é bastante antigo, remontando do século I a.C. Teve início com a utilização das chamadas "noras", ou rodas d'água do tipo horizontal, que produzem energia mecânica pela ação direta de uma queda d'água. Mas foi somente a partir do século XVIII, com o surgimento de tecnologias mais elaboradas, a exemplo do motor, dínamo, lâmpada e da turbina hidráulica, que foi possível converter a energia mecânica em eletricidade. $\mathrm{O}$ acionamento do primeiro sistema de conversão de hidroenergia em energia elétrica do mundo ocorreria somente em 1897, quando entrou em funcionamento a hidrelétrica de "Niagara Falls" (EUA), idealizada por Nikola Tesla com o apoio da Westinghouse. De lá para cá, o modelo é praticamente o mesmo, com a evolução tecnológica, que passou a agregar eficiência e confiabilidade ao sistema. A energia hidrelétrica é a obtenção de energia elétrica por meio do aproveitamento do potencial hidráulico de um rio, cujas águas em movimento (energia cinética) ou oriundas de reservatórios disponíveis (energia potencial), viabilizam a operação de turbinas hidráulicas, cujos eixos são acoplados a um gerador de energia elétrica. Atualmente, as usinas hidrelétricas são responsáveis por aproximadamente $18 \%$ da produção de energia elétrica no mundo, valor esse limitado às condições geográficas naturais que nem sempre favorecem a construção de tais usinas. A viabilidade técnica e econômica da construção de uma usina hidrelétrica requer volumes críticos de água e desníveis favoráveis de curso do leito do rio. As nações que possuem maior potencial hidrelétrico são os Estados Unidos, Canadá, Brasil, Rússia e China. No Brasil, mais de $95 \%$ da energia elétrica produzida é proveniente de usinas hidrelétricas, o que representa 75 milhões de kW. São 158 usinas em funcionamento, enquanto outras 9 encontram-se em construção e 26 foram outorgadas (com permissão para serem construídas). Uma usina hidrelétrica é usualmente classificada de acordo com a sua potência de geração de energia, enquadrando-se em dois tipos principais: as PCHs, ou pequenas centrais hidrelétricas, que produzem de $1 \mathrm{MW}$ a $30 \mathrm{MW}$ e possuem um reservatório com área inferior a $3 \mathrm{~km}^{2}$ (Resolução ANEEL N. ${ }^{\circ}$ 394/98), e as GCHs, ou grandes centrais hidroelétricas, que produzem acima de 30 MW. A Figura 1 ilustra o reservatório de Lajes, no Município de Piraí, RJ, que abastece a Usina Fontes Nova, cujos trocadores dos hidrogeradores vêm sendo estudados por diferentes projetos de $\mathrm{P} \& \mathrm{D}$ em desenvolvimento pela PUC-Rio e que motivaram o presente Projeto Final.

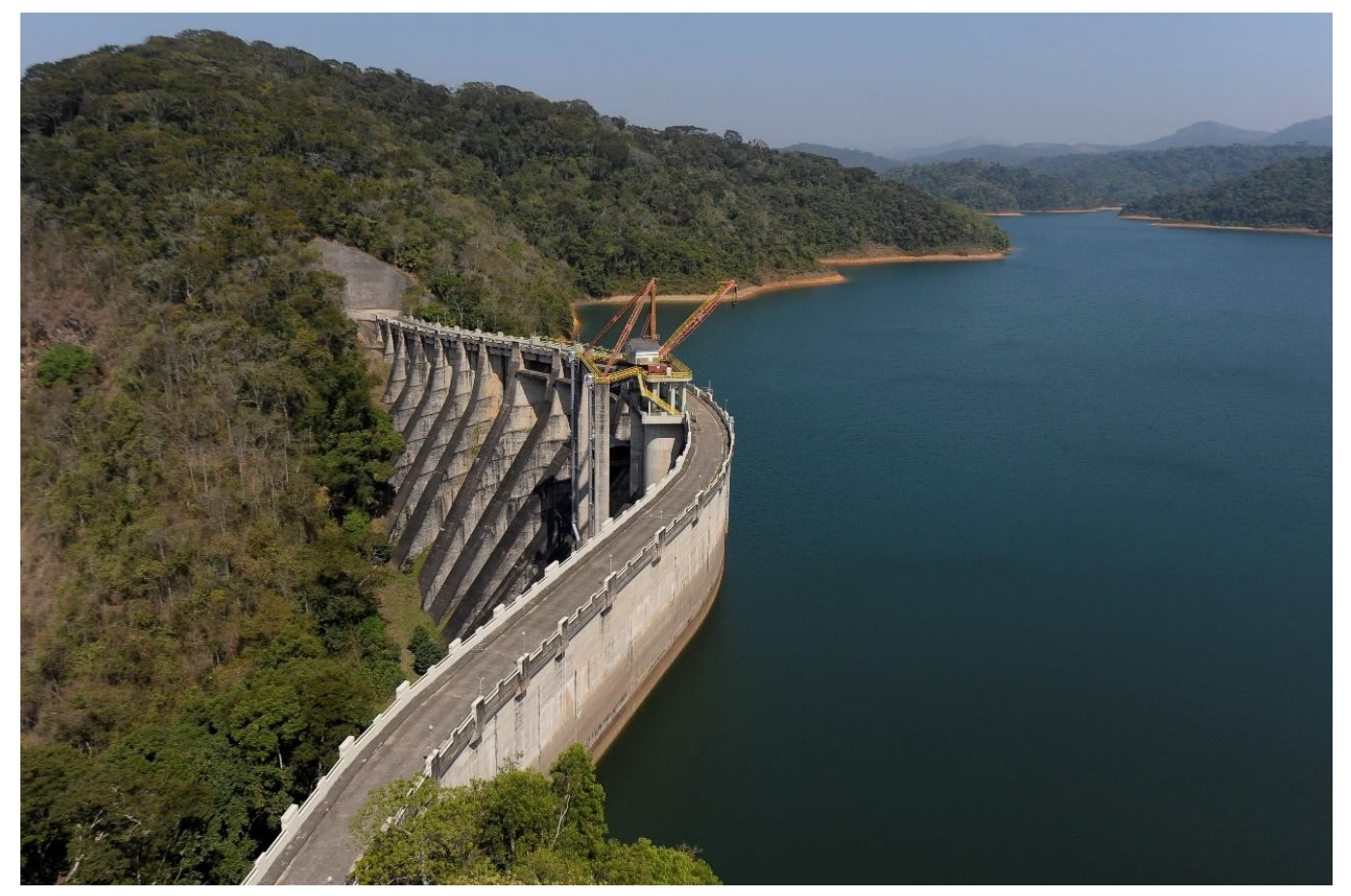

Figura 1: Reservatório de Lajes, fonte de água de abastecimento da Usina de Fontes Nova.

De forma esquemática, a Figura 2 ilustra o esquema de funcionamento de uma usina hidrelétrica, que viabiliza a transformação de energia potencial (energia da água armazenada no reservatório) em energia 
mecânica (movimento das turbinas). As turbinas classificam-se segundo 3 tipos, em função do formato de suas hélices: Kaplan, Francis e Pelton. A escolha do tipo de turbina para uma determinada condição de operação resulta do volume de água e da altura da queda disponível, assim definindo o regime de operação da usina. O gerador (acoplado ao eixo da turbina) é composto por um rotor (ímã), que gira no interior de uma bobina (estator), induzindo a circulação de uma corrente elétrica.

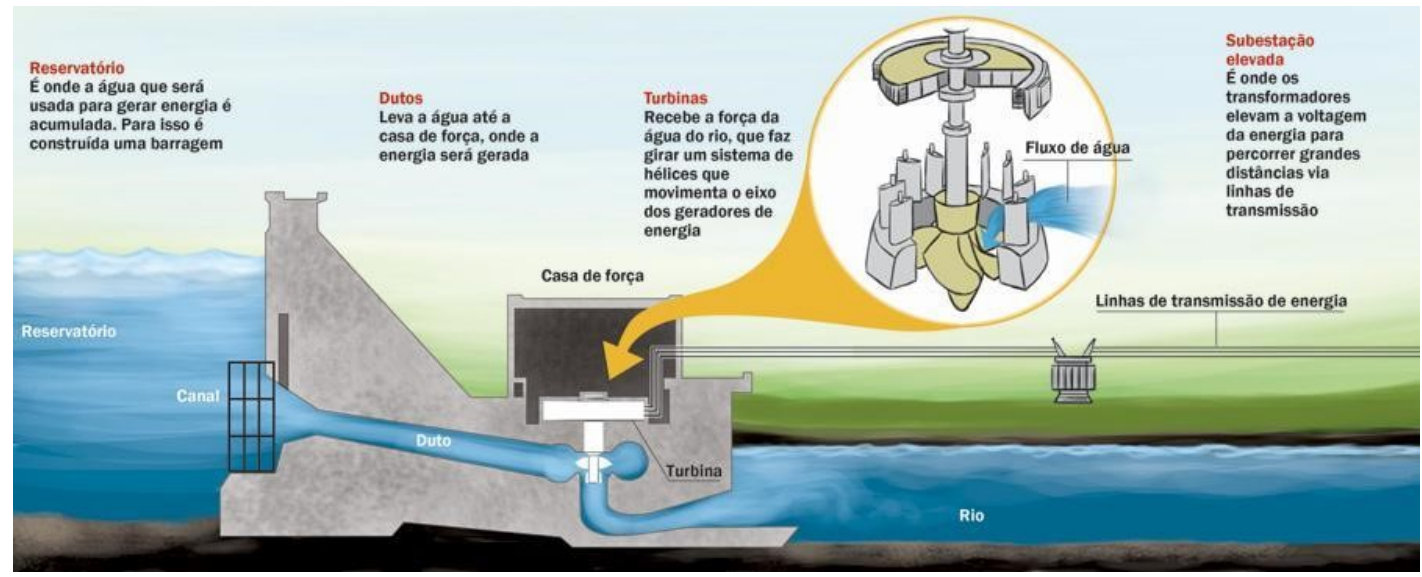

Figura 2: Esquema de funcionamento de uma hidrelétrica.

A preservação da vida útil dos hidrogeradores de uma usina hidrelétrica e o seu adequado funcionamento requerem um sistema de arrefecimento dos diversos componentes motrizes e mancais que o integram. Um sistema de arrefecimento típico opera com diversos componentes, dentre os quais bomba d'água, válvulas e trocadores de calor. 


\subsection{Objetivo}

O objetivo deste projeto final em engenharia mecânica é apoiar e documentar a implantação da automação de um dispositivo de limpeza mecânica de trocadores de calor utilizados no arrefecimento de hidrogeradores. Este trabalho dá sequência a outros trabalhos igualmente desenvolvidos na PUC-Rio, que o antecederam: (i) dissertações de mestrado, que conceberam e construíram um dispositivo mecânico para limpeza de trocadores de calor que faz uso de esferas abrasivas para remover incrustações que se depositam nos tubos internos do trocador [1, 2]; (ii) projetos finais em engenharia, que desenvolveram e otimizaram um sistema optoeletrônico para contar as esferas abrasivas introduzidas e recuperadas pelo dispositivo de limpeza mecânica [3, 4], todos desenvolvidos no âmbito de um projeto específico de P\&D [5], financiado pelo Programa de Pesquisa e Desenvolvimento do Setor Elétrico (Lei no. 9.991, de 24/07/2000, Resolução Aneel 271, de 19/07/2000), que estimula a inovação do setor. Em sintonia com esses desenvolvimentos já consolidados, o presente Projeto Final se desenvolveu prestando apoio ao projeto de $\mathrm{P} \& \mathrm{D}$ em execução.

\subsection{Metodologia}

A metodologia utilizada no desenvolvimento deste trabalho seguiu duas linhas básicas, a saber: (1) estudo da literatura especializada sobre os elementos básicos que fazem interface com os propósitos deste Projeto Final (i.e.: trocadores de calor tubulares; sistemas de limpeza de trocadores de calor; sistemas optoeletrônicos e sistemas de automação e animação) e (2) acompanhamento do desenvolvimento do projeto de $\mathrm{P} \& \mathrm{D}$ em desenvolvimento [5], que objetiva desenvolver o "Cabeça de Série de um sistema inovador de limpeza de trocadores de calor de hidrogeradores". Atuando como estagiária deste projeto, foi possível acompanhar o seu desenvolvimento, em particular contribuir para realizar a transposição do sistema de automação desenvolvido e testado em laboratório até a sua implementação na versão 2.0 do protótipo do sistema de limpeza em desenvolvimento pelo projeto de P\&D [5]. 


\section{Fundamentos Teóricos}

Com o propósito de contextualizar o entendimento deste trabalho, este capítulo sintetiza fundamentos básicos dos subsistemas que serão tratados neste trabalho. São eles: (i) trocadores de calor tubulares; (ii) sistemas de limpeza de trocadores de calor industriais; e (iii) sistemas de automação e animação da automação.

\subsection{Trocadores de Calor}

O trocador de calor é o equipamento usado para implementar a troca de calor entre dois fluidos que estão em diferentes temperaturas e se encontram separados por uma interface, normalmente sólida.

Os trocadores de calor são classificados pelo arranjo do escoamento e pelo tipo de construção. Os exemplos mais comuns são classificados segundo a direção dos fluxos dos fluidos de trabalho, no jargão dos fabricantes usualmente denominados de "fluido quente" e "fluido frio":

- Configuração em paralelo ou Contracorrente: os fluidos quente e frio movem-se no mesmo sentido ou em sentidos opostos em uma construção com tubos concêntricos. Na configuração paralela, ambos entram pela mesma extremidade, escoam no mesmo sentido e deixam o equipamento também na mesma extremidade. Na configuração em contracorrente, os fluidos entram por extremidades opostas, escoam em sentidos opostos e deixam o equipamento em extremidades opostas. A figura 3 ilustra os dois possíveis sentidos de fluxos dos fluidos.

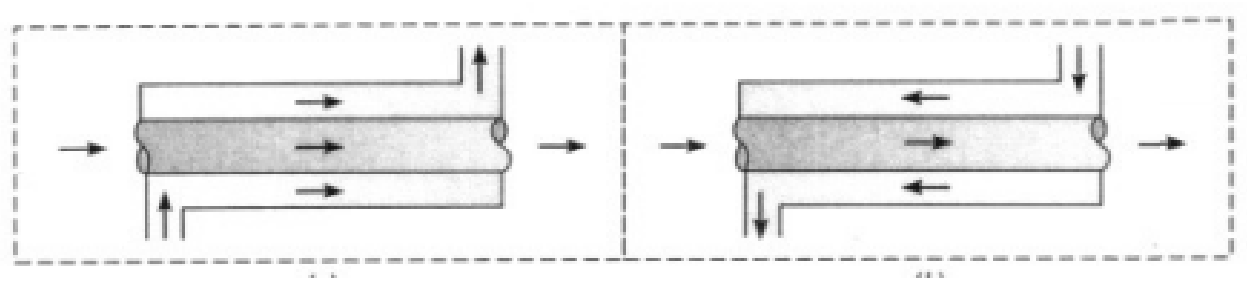

Figura 3: Fluidos movendo no mesmo sentido, e em sentidos opostos, respectivamente.

- Configuração do tipo escoamento cruzado: os fluidos escoam de forma cruzada, um perpendicular ao outro.

a) Tubos aletados:os dois fluidos não se misturam, pois os fluidos quente e frio escoam pelo lado de fora dos tubos, podendo ou não estar misturados. A figura 4 ilustra o escoamento cruzado com fluidos não-misturados

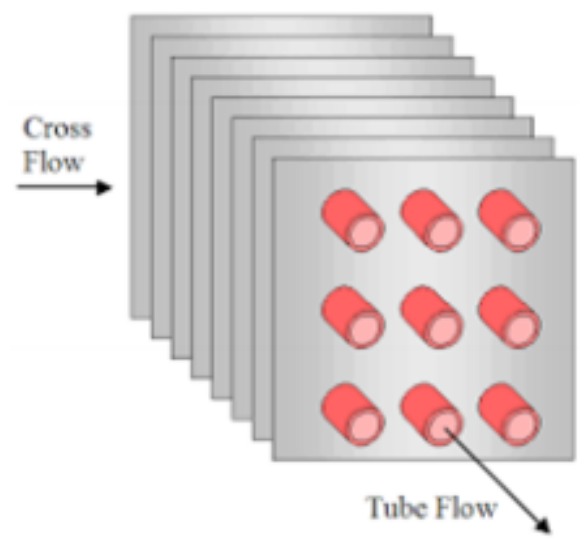

Figura 4: Escoamento cruzado: tubos aletados. 
b) Tubos sem aletas: há mistura de fluidos, e a temperatura tende a variar em decorrência do escoamento na direção perpendicular aos tubos. A figura 5 ilustra o escoamento cruzado com fluidos misturados.

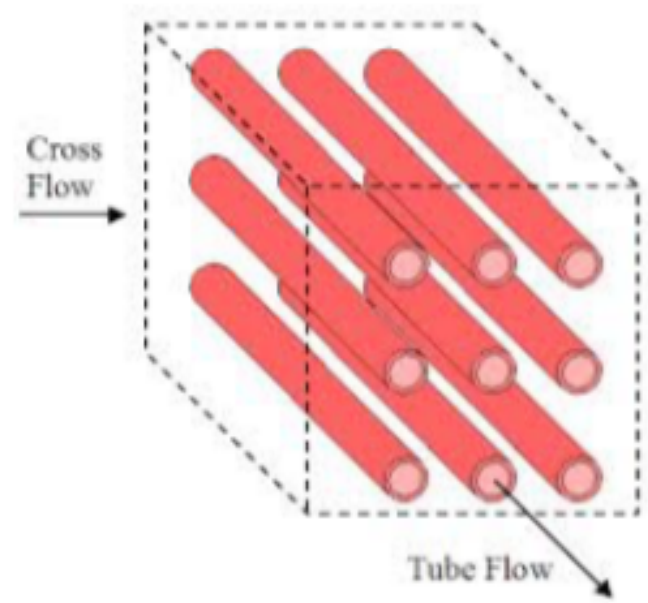

Figura 5: Escoamento cruzado: tubos sem aletas.

- Configuração tubo e carcaça: Formas específicas desse tipo de trocador de calor diferem de acordo com os números de passes no tubo e na carcaça. Além disso, esses trocadores possuem chicanas que suportam os tubos e evitam problemas causados pelas vibrações, e aumentam o coeficiente de transferência de calor no fluido, aumentando assim a convecção forçada sobre os tubos. A figura 6 mostra um exemplo de trocador casco e tubos com um passe no casco e um passe nos tubos (com modo de operação com escoamento cruzado em corrente).

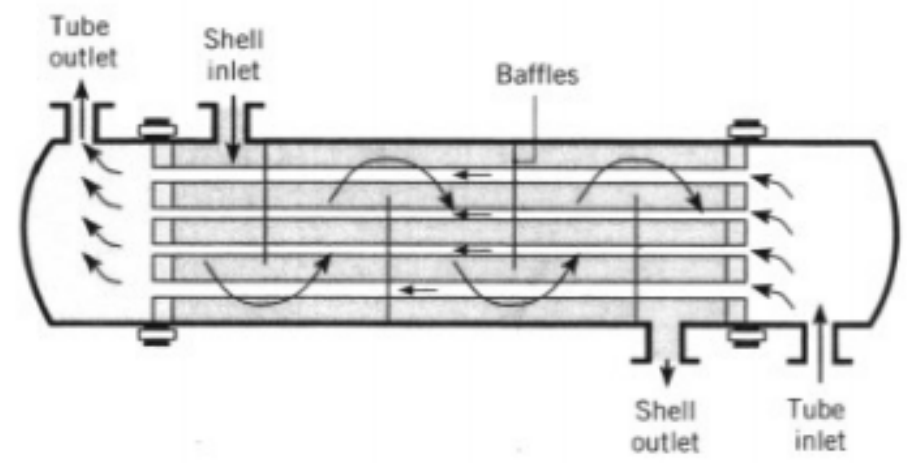

Figura 6: Trocador de calor casco e tubo de um passe.

A queda de eficiência do trocador de calor afeta diretamente a eficiência de geração de energia do hidrogerador, assim trazendo a necessidade de se realizarem limpezas periódicas para que seu funcionamento não seja comprometido. 


\subsection{Sistemas de Limpeza}

A água captada nas represas das usinas hidrelétricas, antes ou mesmo após ter sido utilizada para a geração de energia pelas turbinas é, usualmente, o fluido de trabalho dos trocadores de calor utilizados pelo sistema de arrefecimento dw hidrogeradores. Como há resíduos de natureza orgânica e/ou inorgânica presentes na água das represas, o acúmulo de compostos no interior dos dutos de trocadores de calor é agravado. Esses resíduos formam uma incrustação também conhecida como fouling ou biofouling, afetando a eficiência da operação do trocador e comprometendo a capacidade do sistema de arrefecimento. Esse entupimento dos tubos do trocador, ocasionado pelos depósitos de resíduos e material orgânico presentes nas águas da usina, se não for controlado e eliminado, muito provavelmente poderá resultar em um superaquecimento do hidrogerador, representando perdas de geração e elevados custos de manutenção não programados, que podem requerer a interrupção da usina [1].

\subsubsection{Tecnologias off-line}

Uma das principais tecnologias de limpeza off-line é o processo de lavagem por jato de água: em algumas usinas a técnica por jatos d'água tem sido empregada. Adicionalmente à força aplicada pelos jatos d'água, o choque térmico sobre os depósitos induz rachaduras e posterior fragmentação das incrustações, facilitando a sua remoção. O uso intermitente de jatos e sprays é suficiente para manter uma razoável eficiência do processo de transferência de calor. O aprimoramento da técnica dos sopradores de fuligem resultou na diminuição da utilização da limpeza pelos jatos de água. Em certas ocasiões, o uso da lavagem com água é o último recurso utilizado quando outras alternativas não são eficazes. Essa técnica faz uso de água potável já que o elevado teor de sólidos é o potencial causador de incrustação devido à deposição pela evaporação dos jatos de água. O uso da água do mar em sistemas de refrigeração requer lavagem após o processo, com água potável, para remoção do sal das superfícies de transferência de calor. O efeito da água fria pulverizada sobre a superfície interna dos trocadores de calor, na caldeiraria, pode resultar na diminuição da temperatura do vapor que, por sua vez, reduzirá a eficiência térmica global. Intervenções na temperatura do vapor e da superfície de transferência de calor podem ocasionar danos ao equipamento, particularmente nos tubos da caldeira [1]. É necessário garantir a manutenção da água em termos de quantidade e tempo de aplicação. Dentre as facilidades de utilização dessa técnica destacam-se:

- Jatos simples de água podem ser usados em locais com dificuldade de acesso;

- Podem-se utilizar jatos multibocais para acesso a localidades em que as superfícies não são visíveis pelas portas de inspeção;

- Os depósitos solúveis são facilmente removidos por esta técnica.

Em contrapartida, essas técnicas apresentam as seguintes desvantagens:

- Possível produção de líquidos ácidos a partir da solução de componentes ácidos contidos no gás de combustão, como dióxido sulfúrico que é corrosível;

- Problemas associados com o descarte de efluentes. É necessário considerar as implicações do uso de produtos químicos especiais, como os ácidos minerais, em relação aos potenciais problemas de corrosão;

- Possibilidade de não remover depósitos tenazes e fundidos.

O processo de manutenção que se deseja evitar na Usina Fontes Nova (locus de desenvolvimento do projeto de $\mathrm{P} \& \mathrm{D}$ documentado na referência [5], baseia-se em limpeza por lavagem ou varetagem, ilustrados nas fotos da Figura 7. 


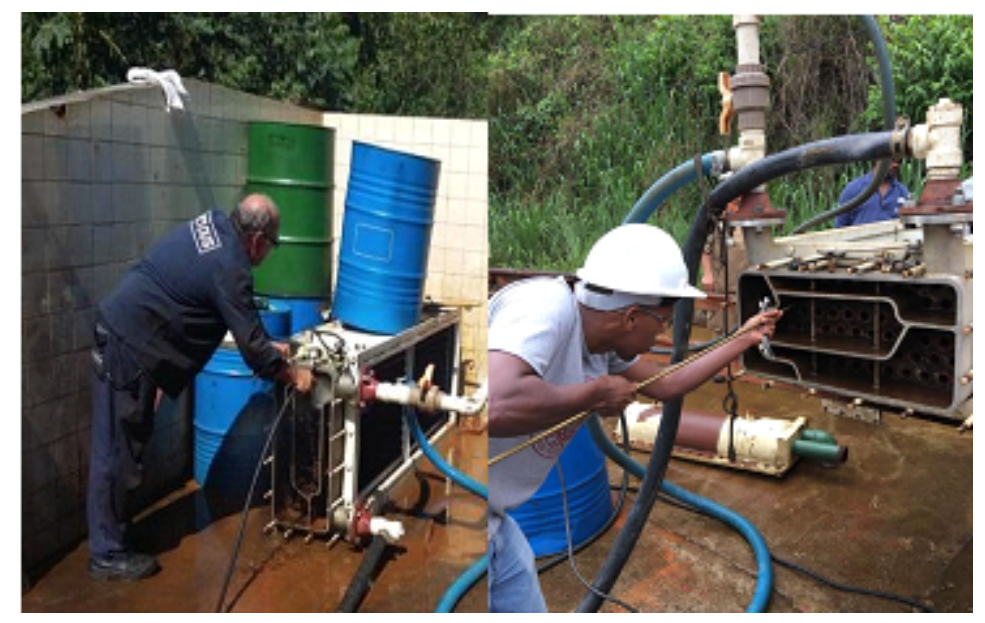

Figura 7: Técnica de limpeza por lavagem (foto da esquerda) e varetagem (à direita).

Tais processos de manutenção, embora triviais, são demorados e onerosos, já que tais operações requerem interrupção da geração e remoção do trocador (tubos de $2060 \mathrm{~mm}$ de comprimento e 22,23 mm de diâmetro nominal, e $550 \mathrm{~kg}$ ) para o pátio de manutenção.

\subsubsection{Tecnologias on-line}

A limpeza on-line é realizada de modo contínuo ou intermitente. Dentre as alternativas tecnológicas destacam-se: injeção de ar e gás, utilização de filtros automáticos (automatic strainers), inversão de fluxo (blackflushing), injeção de produtos químicos (chemical injection), sistemas de varredores e armazenamento (pipeline inspection gauges, PIG) [1].

- Sistema de varredores e armazenamento - Esta tecnologia de limpeza (pipeline inspection gauges, PIG) encontra aplicação nos casos em que as passagens internas dos trocadores de calor possuem seção transversal circular. O princípio desta técnica é a utilização de uma escova de fios metálicos ou filamentos de polímeros apropriados, juntos ao fluido de refrigeração do trocador de calor. Para cada tubo que compõe o trocador de calor há um coletor que armazena e mantém apenas uma única escova após sua passagem. Depois de certo período programado, o fluxo é invertido e o objeto de limpeza retorna pelo interior da passagem dos tubos sendo armazenado na outra extremidade do trocador de calor. A Figura 8, a seguir, ilustra o diagrama de orientação da passagem das escovas no interior do trocador de calor e um modelo de escova geralmente utilizado nesta técnica. O movimento alternado das escovas permite a limpeza das paredes internas dos trocadores. Esta alternativa tecnológica é viável na aplicação em projetos de construção de novas usinas e geralmente utilizada em trocadores de calor individuais de usinas de processo. Cuidados no projeto e operação são necessários para não comprometer a integridade dos tubos dos trocadores. O sistema de varredores e armazenamento é simples e requer pouca manutenção. O seu uso, entretanto, pode ocasionar momentânea interrupção para reversão do fluxo, necessidade de intervenção para assegurar harmonização e qualidade do processo, e manutenção periódica para evitar elevados custos associados à utilização do sistema. 


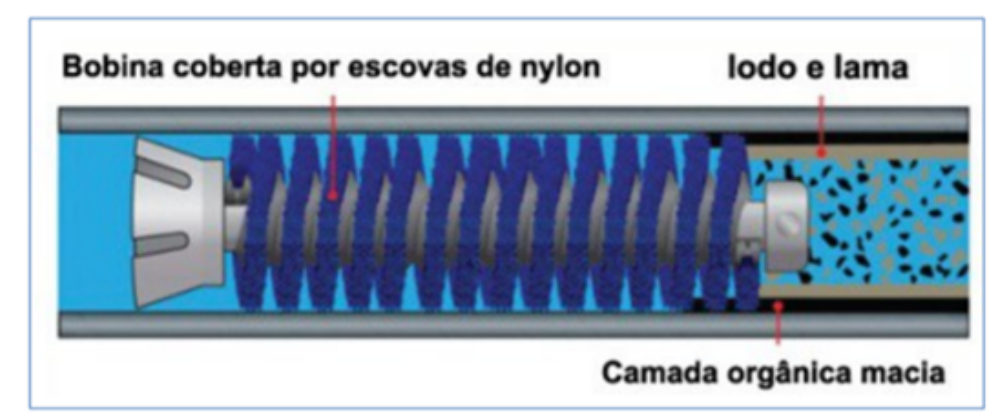

Figura 8: Passagem de uma escova dentro do trocador de calor

- Retrolavagem - A técnica de retrolavagem ou reversão de fluxo consiste em um período curto de remoção dos detritos acumulados nos canais internos do trocador de calor. Esta técnica é realizada por meio da instalação de um bocal com uma válvula de retorno. O fluxo é invertido e as sujeiras são levadas para fora da unidade do trocador. A regulagem da retrolavagem no trocador de calor pode ser eficaz na remoção de partículas ou detritos acumulados nas superfícies internas. Embora esta técnica seja mais econômica que a que faz uso de filtros automáticos, não remove depósitos com elevado grau de incrustação.

- Inserção de esferas abrasivas - Este método consiste em injetar, periodicamente, esferas na linha de circulação de água do sistema para que possa ser feita a remoção dos resíduos depositados nas paredes internas dos tubos, como esquematizado na Figura 9. Elas são feitas de um material esponjoso e possuem cavidades em sua superfície de forma a obter a maior capacidade de absorção possível.

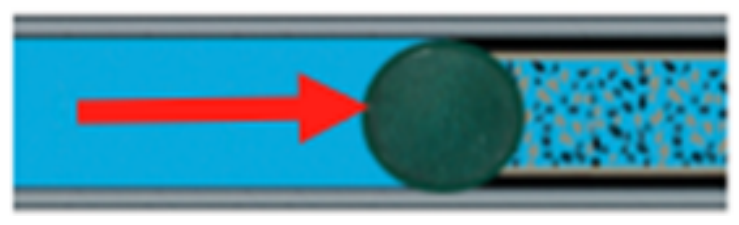

Figura 9: Ação da esfera dentro do duto.

A ideia é que as esferas inseridas trabalhem com uma pequena interferência para que se tenha uma garantia maior de que a incrustação seja removida de forma eficiente a cada passagem das mesmas pelo local crítico. A Figura 10 ilustra a eficácia do processo de limpeza.

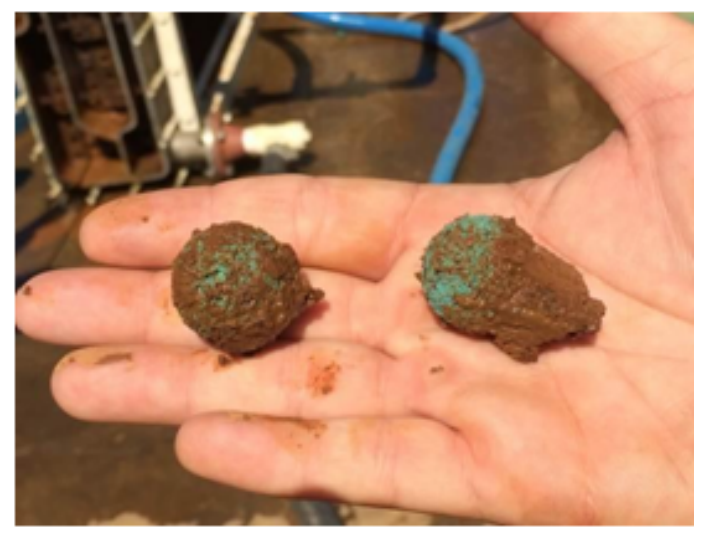

Figura 10: Esferas recuperadas após realizada limpeza. 


\subsection{Automação Industrial}

Sistemas automatizados podem ser aplicados em uma única máquina ou em toda indústria. É chamado de quantidade de "pontos" o número de elementos controlados e monitorados. Tais elementos podem ser válvulas ou servomotores, por exemplo. O processo de controle é semelhante ao diagrama mostrado na Figura 11, onde os citados pontos correspondem tanto aos atuadores quanto aos sensores.

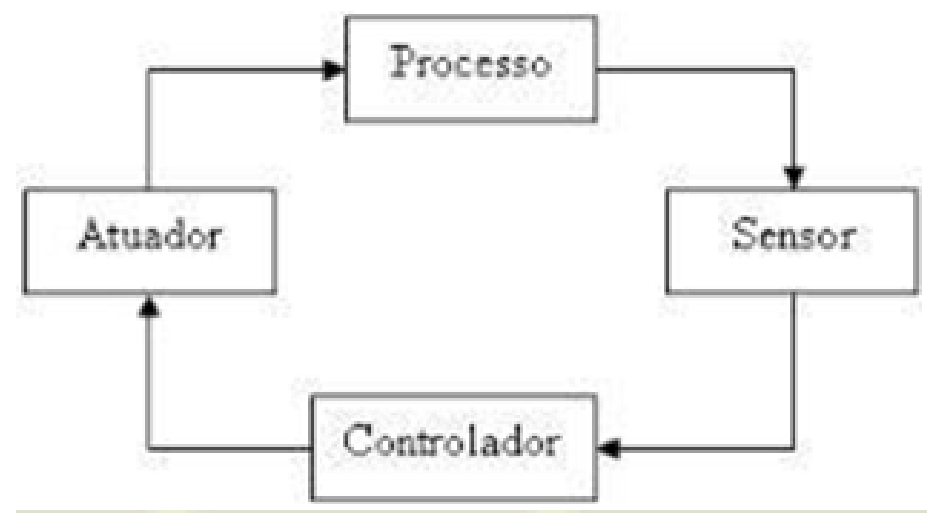

Figura 11: Diagrama simplificado de um sistema automático de Controle.

- Sensores: são os elementos que fornecem informações sobre o sistema, correspondendo às entradas do controlador. Esses podem indicar variáveis físicas, tais como pressão e temperatura, ou simples estados, tal como um fim-de-curso posicionado em um cilindro pneumático.

- Atuadores: são os dispositivos responsáveis pela realização de trabalho no processo ao qual está se aplicando a automação. Podem ser magnéticos, hidráulicos, pneumáticos, elétricos, ou de acionamento misto.

- Controlador (CLP): é o elemento responsável pelo acionamento dos atuadores, levando em conta o estado das entradas (sensores) e as instruções do programa inserido em sua memória.

A comunicação dos elementos de automação obedece a uma "hierarquia" que é similar a uma estrutura organizacional do tipo funcional. A Figura 12 mostra de forma simplificada essa organização.

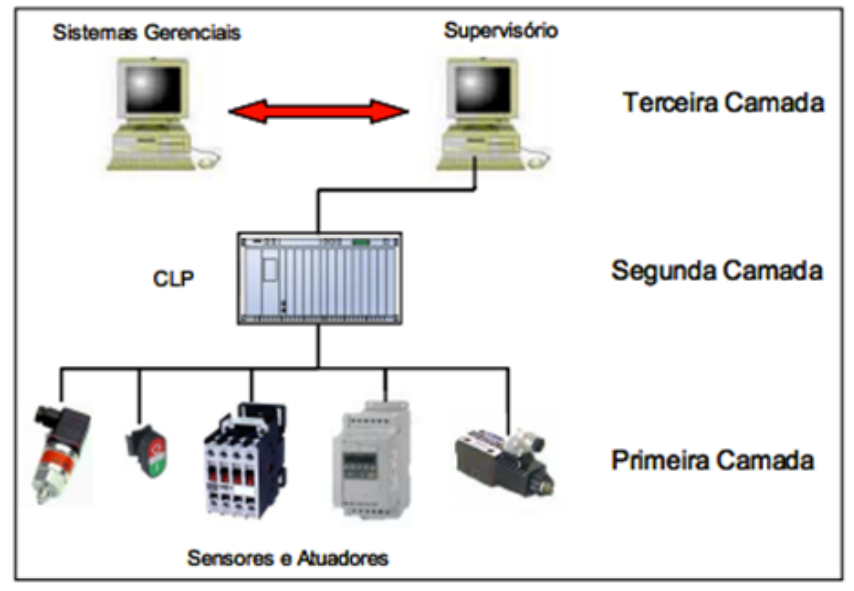

Figura 12: Estrutura organizacional de um sistema automático de controle.

Os elementos mostrados na Figura 11 pertencem à primeira e segunda camadas. Na terceira camada estão os sistemas supervisórios, operados pela "mão humana", onde são tomadas decisões importantes no processo, tais como paradas programadas de máquina e alterações no volume de produção. 
O CLP utiliza informações fornecidas por sensores para controlar um processo. Por meio das instruções gravadas em sua memória interna ele comanda os atuadores, que exercem o trabalho sobre o sistema.

Conceitualmente designam-se os sensores como entradas e os atuadores como saídas, e ambos podem ser representados matematicamente por variáveis. Essas podem ser divididas em variáveis analógicas e digitais, como visto na figura 13.

Variáveis digitais podem ser de valor ou 0 ou 1 . Os sinais digitais se assemelham a uma chave, ou seja, está aberta (0) ou fechada (1). Já variáveis analógicas permitem uma variação infinita de valores entre 0 e 1.

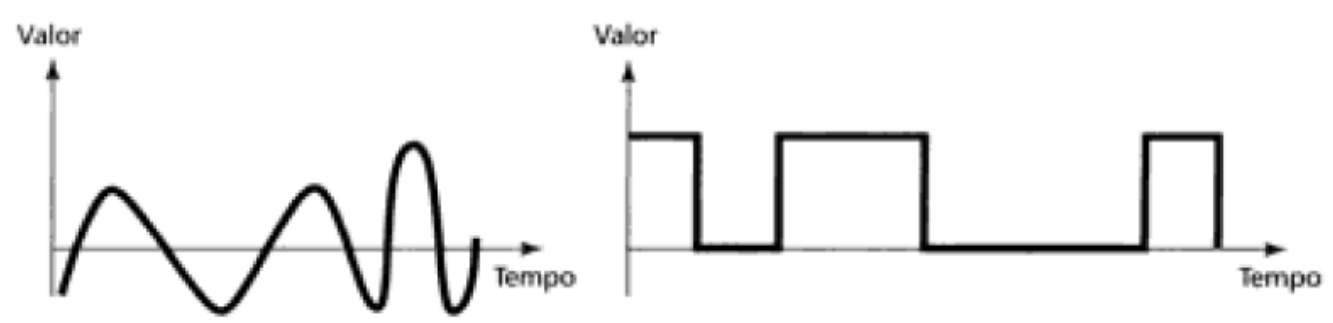

Figura 13: Variáveis de controle analógicas (a) e digitais (b).

Dessa forma podem-se definir as duas formas de Controle: Analógico e Digital.

- Controle Analógico: Processa diretamente os sinais dos transdutores disponíveis usando circuitos de eletrônica analógica.

- Controle Digital: Não pode se comunicar com os sistemas físicos diretamente. Isto porque os sinais físicos reais (temperatura, pressão, etc.) são todos analógicos. Assim, estes sinais devem ser primeiramente convertidos em sinais digitais, processados, e depois convertidos em sinais analógicos novamente. Neste caso, exigem sistemas baseados em microcontroladores, microprocessadores e, no caso considerado neste Projeto Final, Controladores Lógicos Programáveis (CLPs), descritos a seguir.

\subsubsection{Controladores Lógicos Programáveis}

Um dos principais elementos de um processo de controle é o controlador lógico programável, ou o CLP. Este é um tipo de computador utilizado em ambientes industriais sem apoio de equipamentos ou hardwares específicos, e também utilizado em controle e máquinas e processos em diferentes aplicações. A principal diferença entre o CLP e um computador é que o CLP foi projetado para trabalhar em condições industriais extremas, de forma a suportar poeira, vibrações e temperaturas.

A estrutura de um CLP pode ser divida em 4 partes:

- A Unidade de Processamento Central (CPU);

- Seções de entradas e saídas;

- Uma fonte de alimentação;e

- Ciclo de processamento e programa.

Essa estrutura pode ser melhor compreendida através da figura 14. 


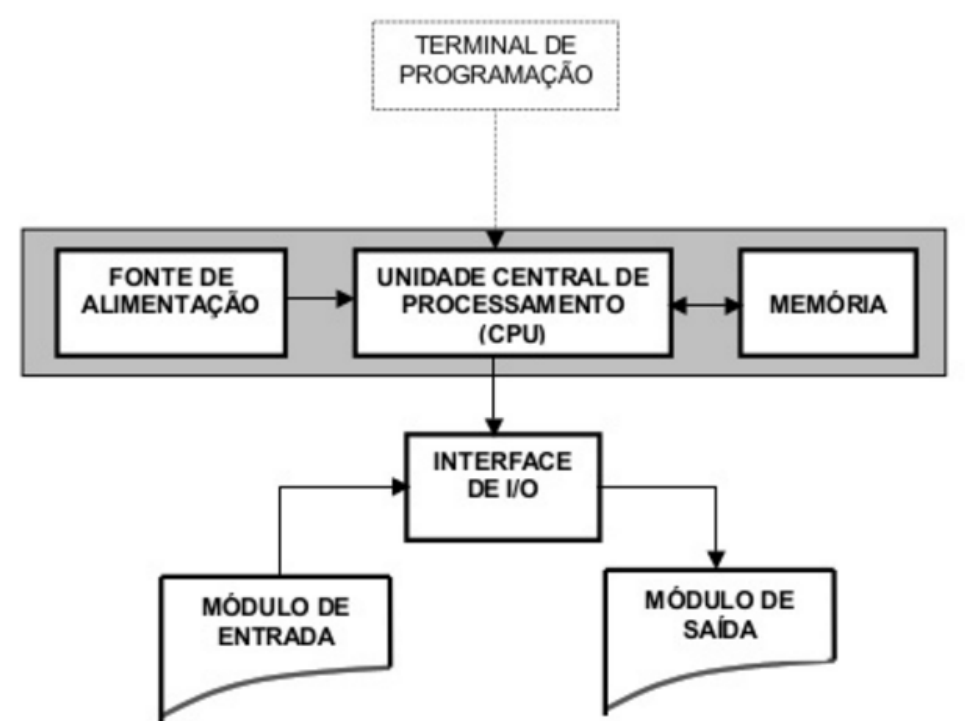

Figura 14: Estrutura básica de um CLP.

\subsubsection{Unidade de Processamento Central (CPU) .}

Esta unidade tem a função de coletar e armazenar os dados enviados pelos módulos de entrada, e efetuar o processamento dos mesmos de acordo com o programa do usuário. Esta unidade fica no slot do CLP, ao lado da fonte de alimentação, como ilustrado na figura 15.

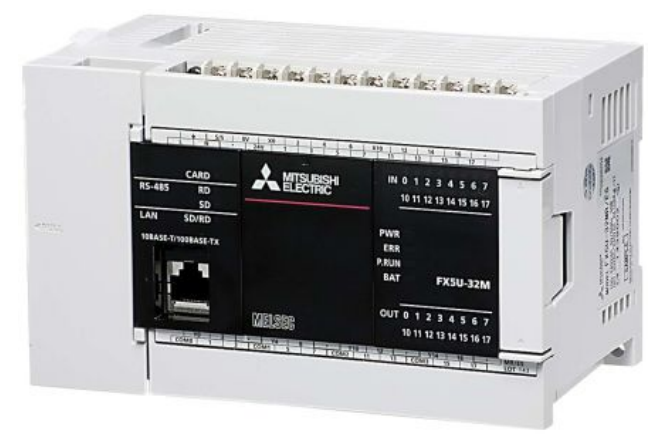

Figura 15: CLP usado no projeto de automação do SIREA.

A CPU é composta de chip de memória, interface I/Os (entradas e saídas), microprocessador e outros circuitos para controlar a lógica e monitorar a comunicação. De modo geral, a CPU possui 4 modos de operação:

- Modo Run: o CLP está a todo momento fazendo a leitura das entradas, processamento e acionamento das saídas, realizando checagens, funções e operações, tudo de acordo com as definições do programa. Neste modo, o CLP se comunica com outros CLPs ou IHMs (Interfaces HomemMáquina). Essas comunicações podem ser de vários tipos: profibus, SCADA, CC link, etc.

item Modo Programação: o CLP faz download da lógica desenvolvida através da conexão com um computador. Após feito o download, a CPU pode ser colocada em modo RUN para rodar o programa. programa.

- Modo Stop: para que as entradas sejam checadas, as saídas precisam ser desligadas, para que isso ocorra o CPU fica "parado", não sendo possível rodar o programa nem fazer textitdownload de software. 
- Modo Reset: neste modo ocorre uma restauração de todos os chaveamentos causados pela lógica do CLP para as condições iniciais de operação. Há dois modos de fazer essa restauração

a) Cold Reset: um reset completo, deletando todas as I/Os de dados de memória.

b) Warm Reset: sem resetar qualquer dado dos registradores de memória.

\subsubsection{Rack e Fonte de Alimentação .}

A fonte de alimentação fornece energia a todos os elementos que compõem o CLP. Podem possuir baterias para garantir o funcionamento do mesmo.

O Rack fornece uma estrutura física para os I/Os e uma conexão elétrica dos barramentos entre os módulos. Esses barramentos são dados que estabelecem links de comunicação entre os módulos I/Os e o controlador. O Rack é responsável por interconectar partes do CLP e permitir a alimentação e a comunicação entre elas.

A fonte de energia no Rack fornece alimentação em corrente contínua de $24 \mathrm{~V}$ e $5 \mathrm{~V}$.

\subsubsection{Entradas e Saídas .}

\section{a) Entradas}

Elementos responsáveis por transmitir sinais para o CLP. Esta entrada pode ser de vários tipos: digital, analógica, chaveamento, sensores, entre outros. Desta forma, é possível especificar o módulo de entrada digital ou um cartão a fim de ligar sinais digitais. O CLP utilizado no projeto, Mitsubishi modelo FX5U-32MR/ES, possui 16 entradas digitais.

\section{b) Saídas}

Os módulos de saída podem ser também digitais ou analógicos. Uma observação sobre os CLPs é que eles são capazes de converter sinais. O fluxo da informação é: o cartão de entrada analógica converte o sinal para digital (conversão A/D), após isso, o programa processa a informação e envia para um cartão de saída analógica que converte para o sinal analógico (conversão D/A). O cartão de saída digital faz acionamentos como ligar ou desligar lâmpadas, válvulas solenoides, relés e contadores. Estes módulos possuem de 8 a 128 entradas por cartão, sendo que o CLP do projeto possui 16 saídas digitais.

\subsubsection{Ciclo de Processamento e Programa .}

O ciclo de funcionamento de um CLP baseia-se em um processo conhecido como Scan ou Varredura. O CLP trabalha e processa os I/Os, o programa de operação e as checagens de erros. O Tempo de Scan (Scan Time) é o tempo que o CLP leva para completar um loop nesse processo. O Scan Time é da ordem de $1 / 10^{6}$ de segundo.

Inicialmente o CLP realiza um Scan nas entradas e após isso executa o programa que fica armazenado na memória ROM (se a energia do sistema for cortada, não é perdido o programa). Dentro deste Scan o CLP executará operações programadas no software aplicativo, como intertravamentos, armazenagem de dados processados na memória de dados, entre outas ações.

Após feito o Scan, o CLP atualiza as saídas de acordo com as condições com o programa, e paralelamente recebe novos dados de entradas para alimentar a memória de dados. O ciclo de funcionamento está ilustrado na figura 16. 


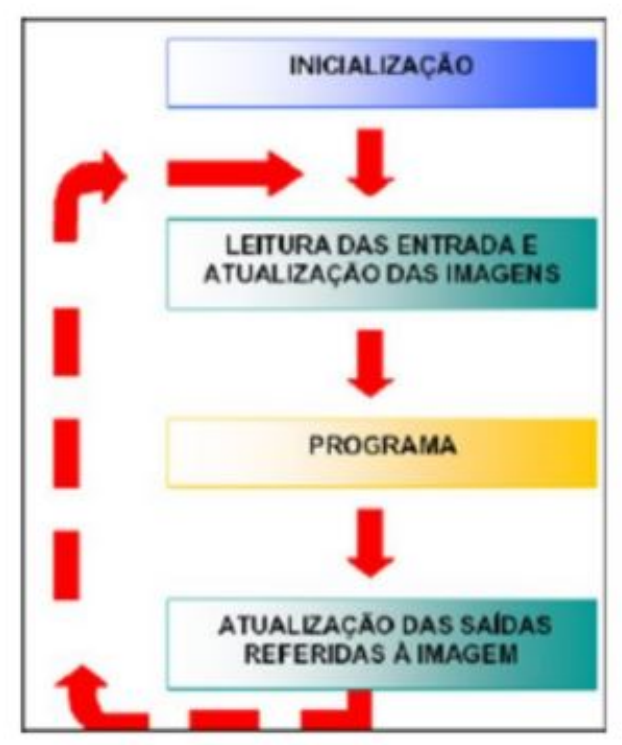

Figura 16: Ciclo de funcionamento do processamento do CLP

Para programar o CLP é necessário instalar um software dedicado para o CLP em questão. O software escolhido para este projeto foi o Indusoft, que será abordado com maior profundidade mais à frente.

A linguagem de programação utilizada é uma linguagem gráfica: Diagrama Ladder, que é muito utilizada, pois consegue representar os circuitos elétricos com bastante realismo, como visto na figura 17.

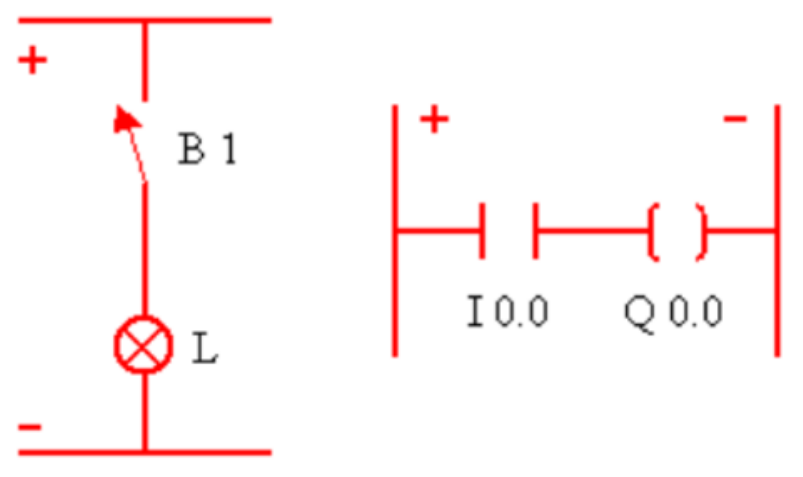

Figura 17: Diagrama elétrico à esquerda e diagrama em Ladder à direita do acionamento de uma lâmpada.

\subsubsection{Sistema de Supervisão e Aquisição de Dados (SCADA])}

SCADA (Supervisory Control And Data Aquisition) é um sistema de supervisão de software que, através da aquisição de dados e envio de comandos, controla e supervisiona um processo industrial.

Os sistemas SCADA são divididos em dois módulos: modo de desenvolvimento e modo de execução, ou run-time.

Os módulos de desenvolvimento dos softwares SCADA possuem uma interface gráfica, o que possibilita a criação de objetos do processo a serem monitorados.

Para que esse monitoramento seja feito, é necessário estabelecer uma comunicação entre o software e os equipamentos, pois através dessa comunicação é possível enviar comandos para acionamento de um sistema hidráulico, visualizar valores medidos através de sensores, entre outras possibilidades. É possível também diagnosticar eventos que acontecem no processo, receber informações em tempo real, podendo diagnosticar possíveis falhas. 
É possível gerar relatórios das informações armazenadas pelo sistema SCADA.

Na figura 18 é ilustrado um sistema SCADA composto por dois CLPs.

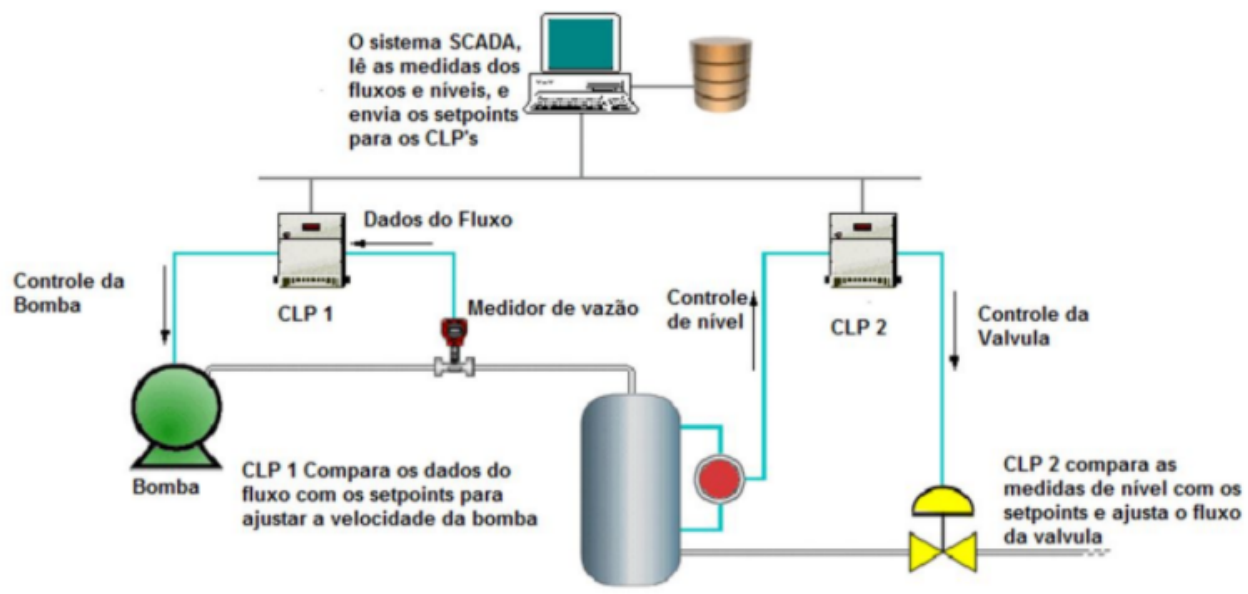

Figura 18: Dois CLPs monitorados por um sistema SCADA.

\subsubsection{Interface Homem Máquina (IHM)}

Uma IHM é uma interface gráfica que permite a interação entre homem e máquina. As IHMs surgiram da necessidade de uma interface amigável entre sistemas complexos e os responsáveis pela operação. As funções mais comuns de uma IHM são: mostrar mau funcionamento, monitorar níveis, permitir que o operador execute ações como iniciar ou interromper ciclos, gerar gráficos, entre outras.

Para sistemas grandes, muitas vezes são usadas IHMs que fornecem melhor qualidade de monitoramento, equipadas com memórias grandes e cartões SD. Essas IHMs geralmente envolvem um software SCADA ou MES, que são sistemas de supervisão que geralmente rodam em sistemas operacionais como Windows. Esse tipo de IHM que necessita de aplicações de alto desempenho é também conhecido como PC Industrial.

Além dessas vantagens, o PC Industrial tem maiores opções de comunicações como Profibus, Ethernet, Modbus, TCP/IP.

No caso do projeto SIREA, é usado um PC Industrial da marca Advantech, modelo TPC-1251T, ilustrado na figura 19, e a comunicação do tipo Ethernet e Modbus. 


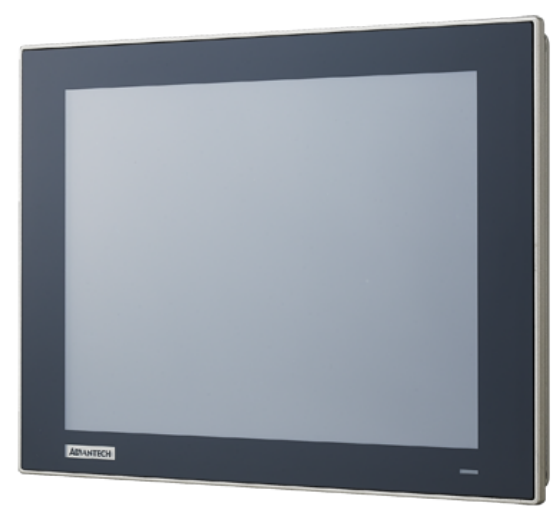

Figura 19: PC Industrial Advantech.

\section{Contador de Esferas: Gerador de Sinais para Automação}

O contador de esferas refere-se a um sistema inteligente que controla o número de esferas abrasivas injetadas e recuperadas durante o processo de limpeza, alarmando não-conformidades e acionando a abertura e fechamento das servo-válvulas do sistema de automação do SIREA como um todo. Além disso, o contador também tem o propósito de gerar pulsos lógicos para orientar o sistema de automação a operar as servo-válvulas introduzidas no SIREA para viabilizar a sua automação [6].

O sistema faz uso de sensores optoeletrônicos infravermelhos, cujos sinais são microprocessados para alimentar um algoritmo de controle, assim agregando inteligência ao sistema.

A versão preliminar (1.0) do contador, que foi desenvolvida por Kim Carvalho como Projeto Final em Engenharia Mecânica pela PUC-Rio, baseou-se no sensor Honeywell HOA 6299, ilustrado na figura 20.

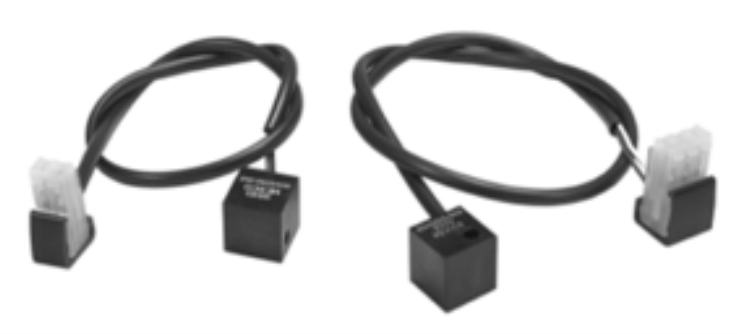

Figura 20: Sensor Honeywell HOA 6299.

Porém, este sensor não atende às necessidades do sistema em condições reais de operação, em que as esferas circulam em meios turvos causados pela água suja proveniente do processo de remoção do fouling. Características fornecidas pelo fabricante do sensor confirmam que este é capaz de detectar qualquer objeto opaco que tenha tensão de $0,4 \mathrm{~V}$ de sinal de saída, entretanto, em meios turvos, ocorre significativa queda na tensão de resposta do receptor. 
Além disso, mais dois problemas deveriam ser solucionados: :

1ㅜ: Necessidade de medir a velocidade da esfera, a fim de obter a largura de um único sinal

$2^{\circ}$ : Necessidade de um rigoroso alinhamento entre transmissor e receptor do sinal optoeletrônico

Para solucionar esses problemas, mais especificamente o item (i), foi desenvolvida a versão 2.0 do contador de esferas abrasivas, usando outros componentes optoeletronicos: um LED SEP8736 e um fototransistor SDP8436, ilustrado na figura 21. Esses componentes possuem saída digital a partir de um limiar fixo de deteç̧ão. Desta forma, pode-se ajustar esse limiar e adequá-lo ao sistema a meios com maior turbidez.

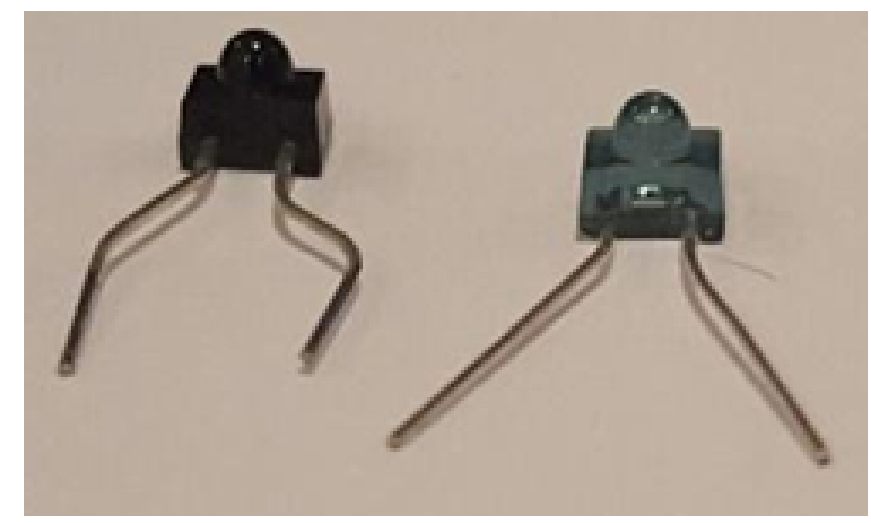

Figura 21: LED SEP8736 e o fototransitor SDP8436.

O esquema da Figura 22 apresenta o circuito eletrônico de condicionamento e leitura para estes novos componentes optoeletrônicos.

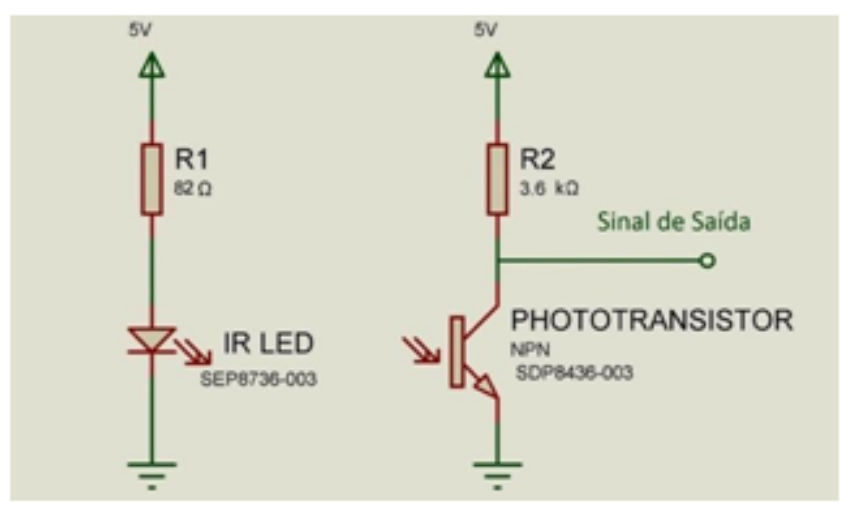

Figura 22: Circuito eletrônico dos novos componentes.

Foram feitos testes para implementar esse contador. Fazendo uso de um voltímetro foi possível simular a detecção das esferas. Para realização desses testes foi montada uma bancada experimental com tubo vedado e a esfera inserida, ilustrado na figura 23. 


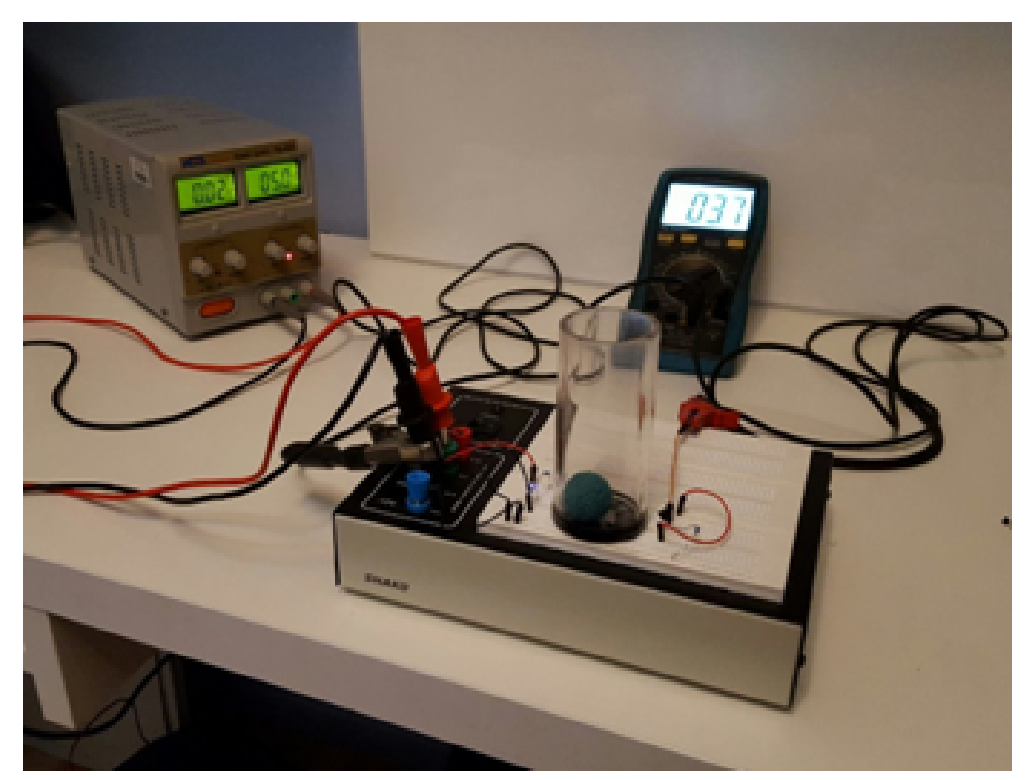

Figura 23: Bancada Experimental: sensores-tubo-esfera abrasiva.

Foram adicionadas diferentes concentrações de corantes para testar diferentes medições de variação de tensão. Ensaios foram realizados para seis diferentes concentrações de corantes, variando entre 0,25 $\mathrm{ml} / \mathrm{l}$ até 6,0 ml/l, conforme ilustrado na Figura 24, obtendo-se, assim, as tensões médias [4], conforme mostrado na Figura 25, que ilustra a variação da tensão em função do aumento da concentração de corante.

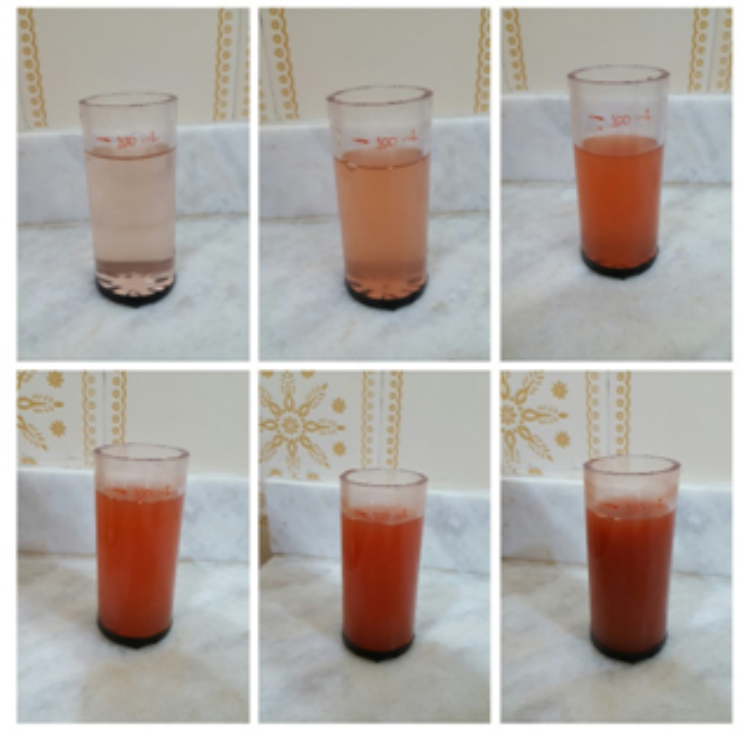

Figura 24: Concentrações de corantes: 0,25ml/1, 0,75 ml/1, 1,50 ml/1, 2,25 ml/1, 3,0 ml/1 e 6,00 ml/1.

A partir da concentração $3 \mathrm{ml} / \mathrm{l}$, a tensão medida passou a variar em valores cada vez menores. Mesmo assim, para todos os ensaios realizados (com todas as concentrações), ainda foi possível realizar a detecção da esfera.

Portanto, com os resultados obtidos, foi gerado um gráfico com a resposta dos sensores em função da concentração de cada ensaio realizado, apresentado na Figura 25.

Este gráfico comprova a viabilidade da utilização do LED SEP8736 e do fototransistor SDP8436 em meios turvos. 


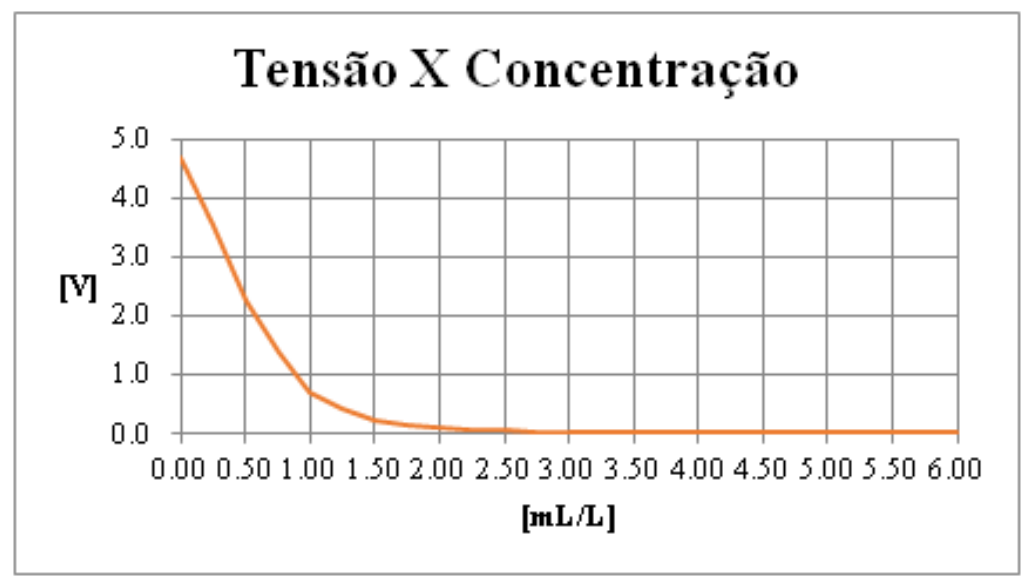

Figura 25: Queda de tensão do fototransitor devida à adição de corante.

Além disso, dois mecanismos foram incorporados ao contador de esferas para minimizar a detecção de "falsos positivos" [6].

a) Utilização de dois feixes infravermelhos a utilização de dois feixes infravermelhos defasados 90 graus entre si, conforme ilustrado na figura 26, reduz a ocorrência de falsos positivos.

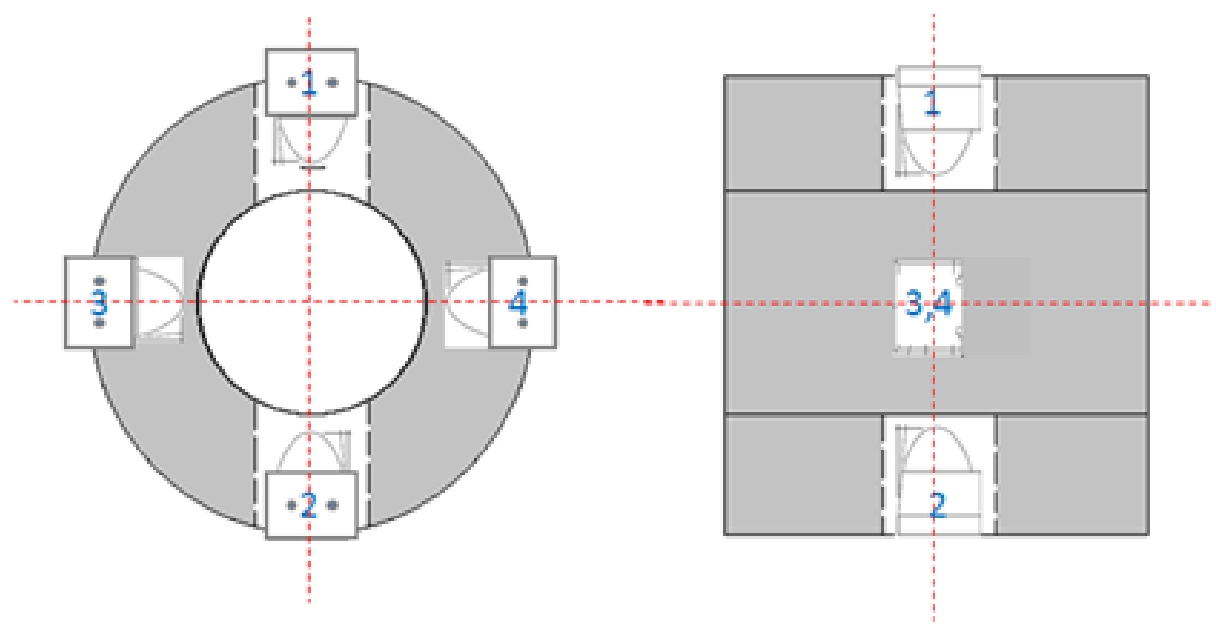

Figura 26: Esquema de detecção com 2 feixes infravermelhos defasados de 90 graus entre si. (a) Vista frontal. (b) Vista lateral.

A passagem de um objeto é detectada somente se os feixes forem interrompidos simultaneamente, para que isso ocorra é preciso que o objeto passe exatamente no centro da seção reta do tubo. [6]

\section{b) Estimativa da velocidade linear das esferas}

Considerando

i. que as esferas têm diâmetro nominal conhecido, e a perda de diâmetro é pequena e pode ser monitorada; e

ii. que o SIREA opera com vazão otimizada com velocidade linear de aproximadamente $1 \mathrm{~m} / \mathrm{s}$ 
É possível utilizar o contador de esferas para estimar a velocidade das mesmas, e através dessa velocidade é possível descartar os falsos positivos. O princípio de detecção de velocidade é baseado conforme a figura 27: na posição do instante t1 o feixe é interrompido e assim permanece até a esfera atingir a posição do instante t2 [6].

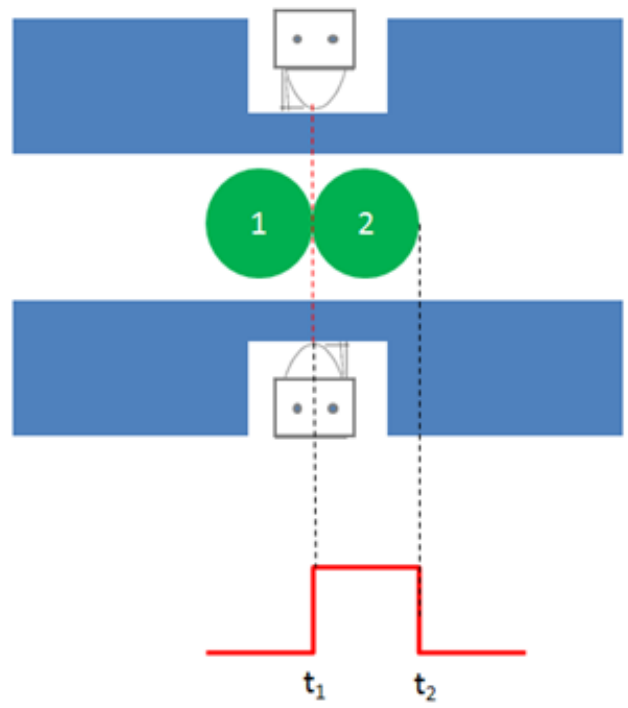

Figura 27: Princípio de estimativa da velocidade linear das esferas, com base na largura do pulso de deteç̧ão.

Este sistema optoeletrônico está em fase de testes finais. Uma ótima resposta do contador é, por exemplo, quando duas esferas são lançadas em instantes muito próximos, separadas de apenas $1 \mathrm{~mm}$. A figura 28 ilustra o pulso que essas duas esferas geram, sendo o primeiro pico igual a $0,01677 \mathrm{~s}$, maior que o segundo, igual a $0,01506 \mathrm{~s}$.
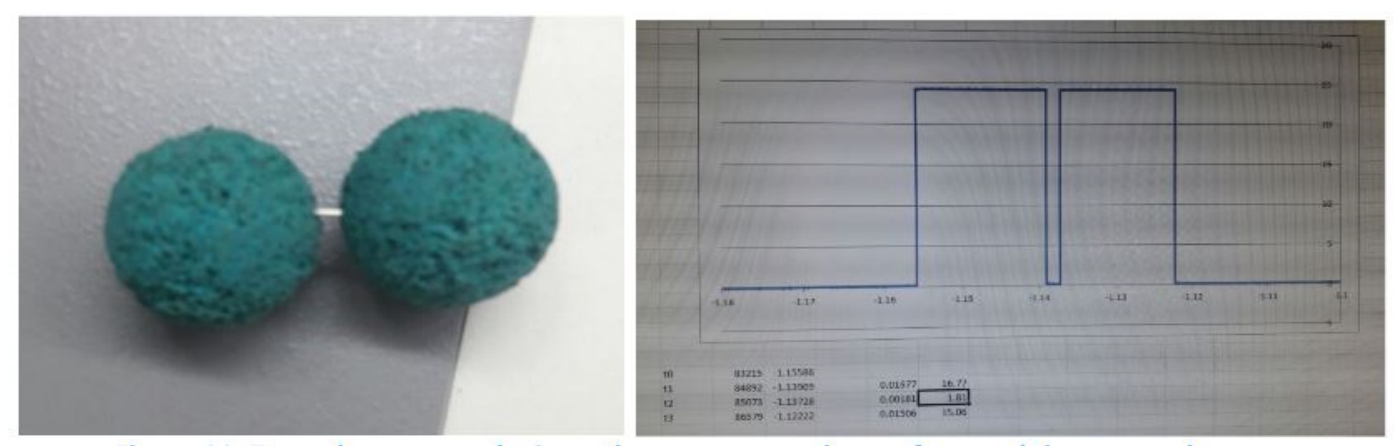

Figura 28: Resposta de captura de esferas próxima.

Para solução do $2^{\mathrm{o}}$ problema que havia sido identificado, foi implantado um circuito eletrônico em PCB (printed circuit board - placa de circuito impresso), que força o alinhamento adequado dos elementos sensitivos: 2 LEDs (emissores) e 2 fototransitores (receptores). Para que esta solução fosse implementada foi necessário um dimensionamento detalhado da espessura mínima da parede que se interpõe entre a face do elemento sensitivo e a parede interna do espaço tubular, por onde circula a água de resfriamento do trocador de calor que transporta as esferas abrasivas. 
O material escolhido para o contador de esferas foi uma resina acrílica (POLIMETILMETACRILATO, PMMA), escolhida em função de:

i. Seu limite de escoamento (25 Mpa): o material deve ser capaz de resistir à pressão do escoamento que transporta as esferas;

ii. Sua transparência: essencial para que ocorra a propagação do feixe de luz na faixa infravermelho e vença a turbidez da água.

Na figura 29 é ilustrado o modelo do contador.

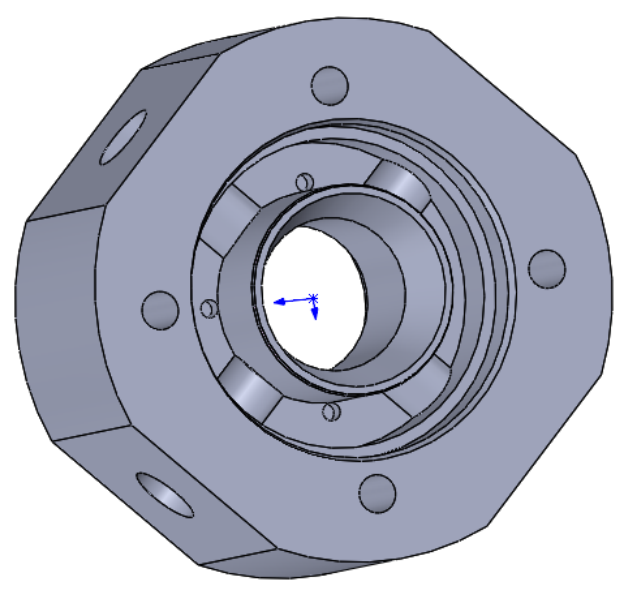

Figura 29: Contador de esfera modelado em CAD.

Após análise das tensões admissíveis, a espessura mínima de parede foi calculada utilizando critério de vasos de pressão de paredes finas (GERE \& GOODNO, 2010)

$$
P\left(\frac{D_{e}}{2 t}+1\right)=\frac{S e}{F S}
$$

Nesta expressão, P é a pressão de trabalho (6 bar $=0,5 \mathrm{MPa})$; De é o diâmetro externo $(41 \mathrm{~mm})$; t é a espessura da parede; Se é o limite de escoamento (25 MPa) e FS, o fator de segurança adotado. Considerando a hipótese $\mathrm{FS}=1$, consegue-se determinar $\mathrm{t}=0,51 \mathrm{~mm}$ (espessura mínima de parede). Com larga margem de segurança, a usinagem foi feita mantendo-se um valor de $\mathrm{t}=3 \mathrm{~mm}$ (o que resulta em FS $=5,3$ ), já que $3 \mathrm{~mm}$ não causa atenuação significativa para a propagação do feixe óptico [6].

A Figura 30 mostra a tampa da cavidade onde a eletrônica do contador encontra-se embarcada, tampa essa dotada de anéis de borracha do tipo "O", para proteger o circuito eletrônico de possível contaminação por água e outros agentes externos [6]. 


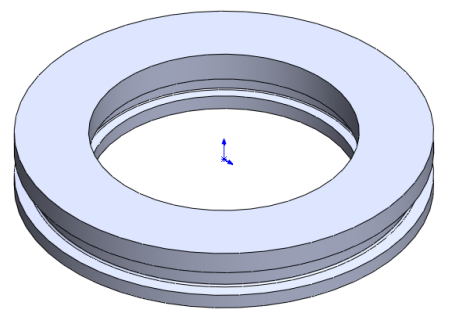

Figura 30: Tampa do contador de esferas modelada em CAD.

O principal desafio do projeto da placa PCB foi a disposição dos componentes e elementos do circuito em uma área restrita de $22 \mathrm{~cm}^{2}$. Alguns desses componentes possuem uma posição fixa relativa à furação do bloco e outros foram posicionados de forma a minimizar a distância entre as trilhas (conexões entre os componentes) [6]. A posição inicial dos componentes está ilustrada na figura 31.

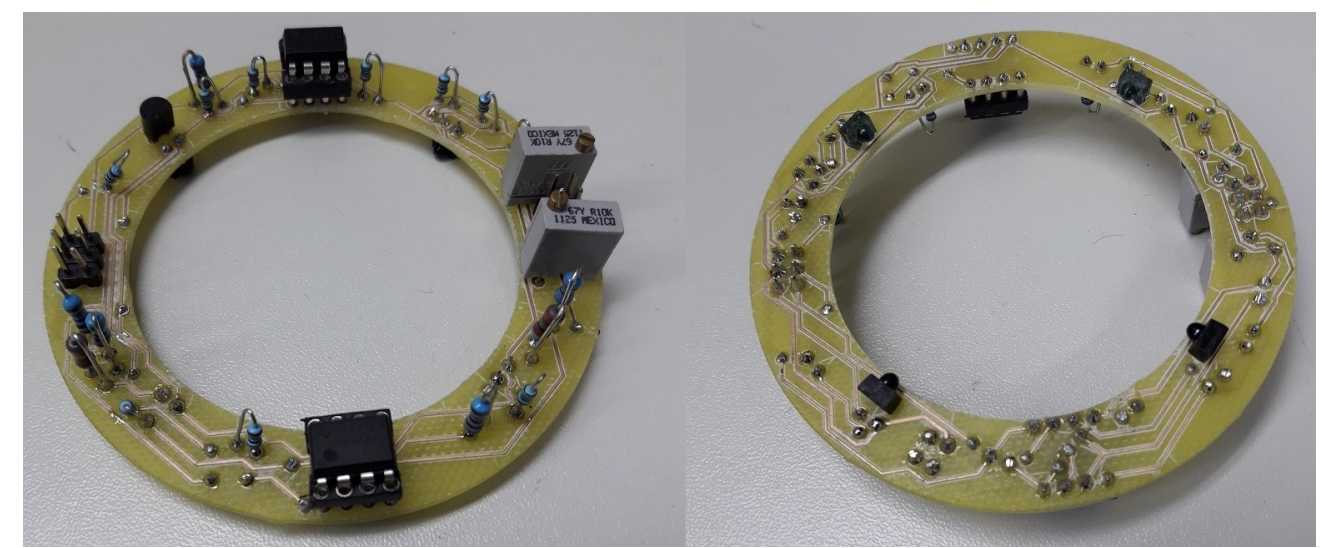

Figura 31: Circuito completo com a montagem dos componentes.

Para fabricação do protótipo foi utilizada uma máquina CNC modelo S103 do fabricante LPKF, em operação no Laboratório de Pesquisa e Desenvolvimento em Eletrônica (LPDE) da PUC-Rio. Os fototransistores e os fotodiodos foram montados na face inferior do bloco de acrílico, posicionados abaixo da linha do PCB garantindo o auto alinhamento dos feixes ópticos. O bloco montado com a placa PCB está ilustrado na figura 32. 


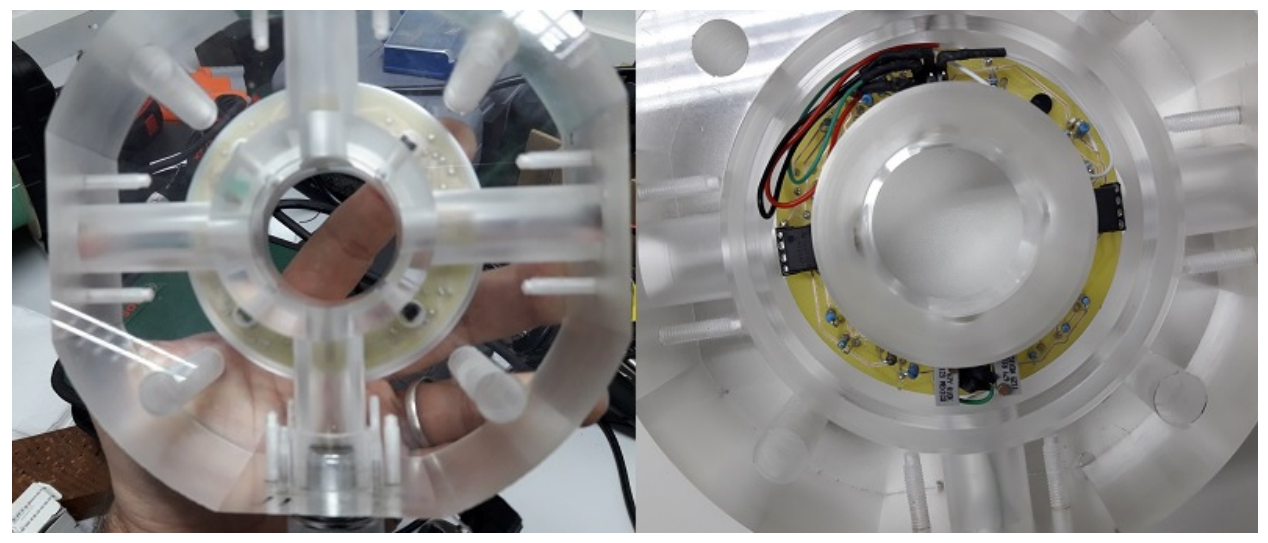

Figura 32: PCB montado no bloco de acrílico.

Para finalizar a montagem do contador de esferas, escolheram-se conectores que possuem o-rings de vedação, ilustrados na figura 33, próprios para utilização em ambiente industrial: modelos MT20-F7PRC-S-S e MT20-M7-RQP-S-S da marca Weipu [6].

A figura 34 ilustra a montagem final do PCB, bloco e conectores.
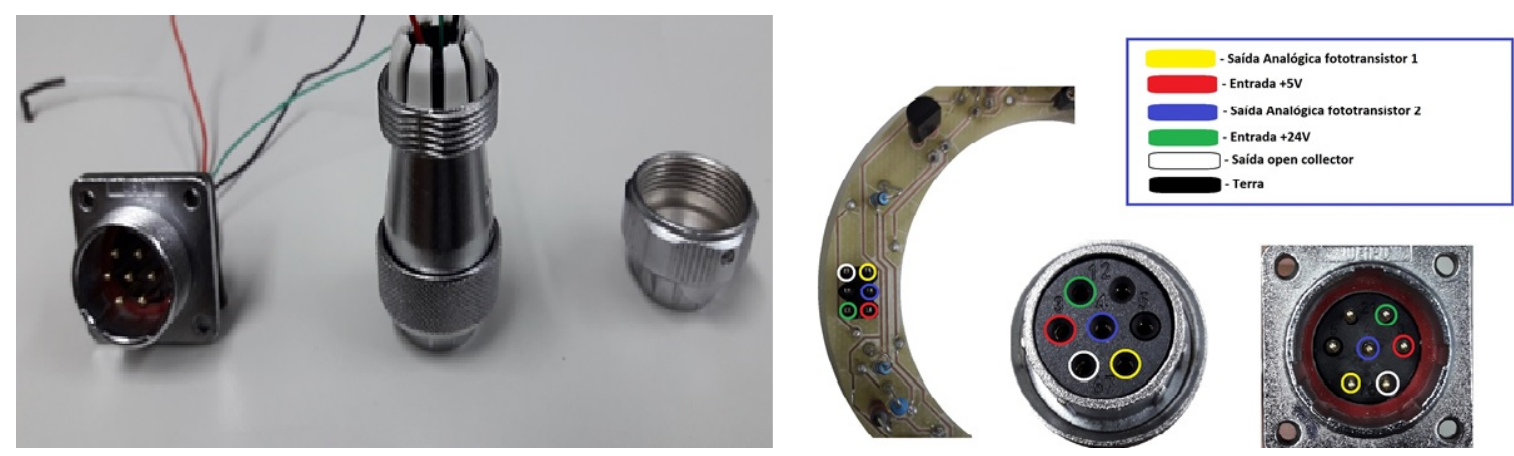

Figura 33: Parte do conector e pinagem entre PCB e conector. 

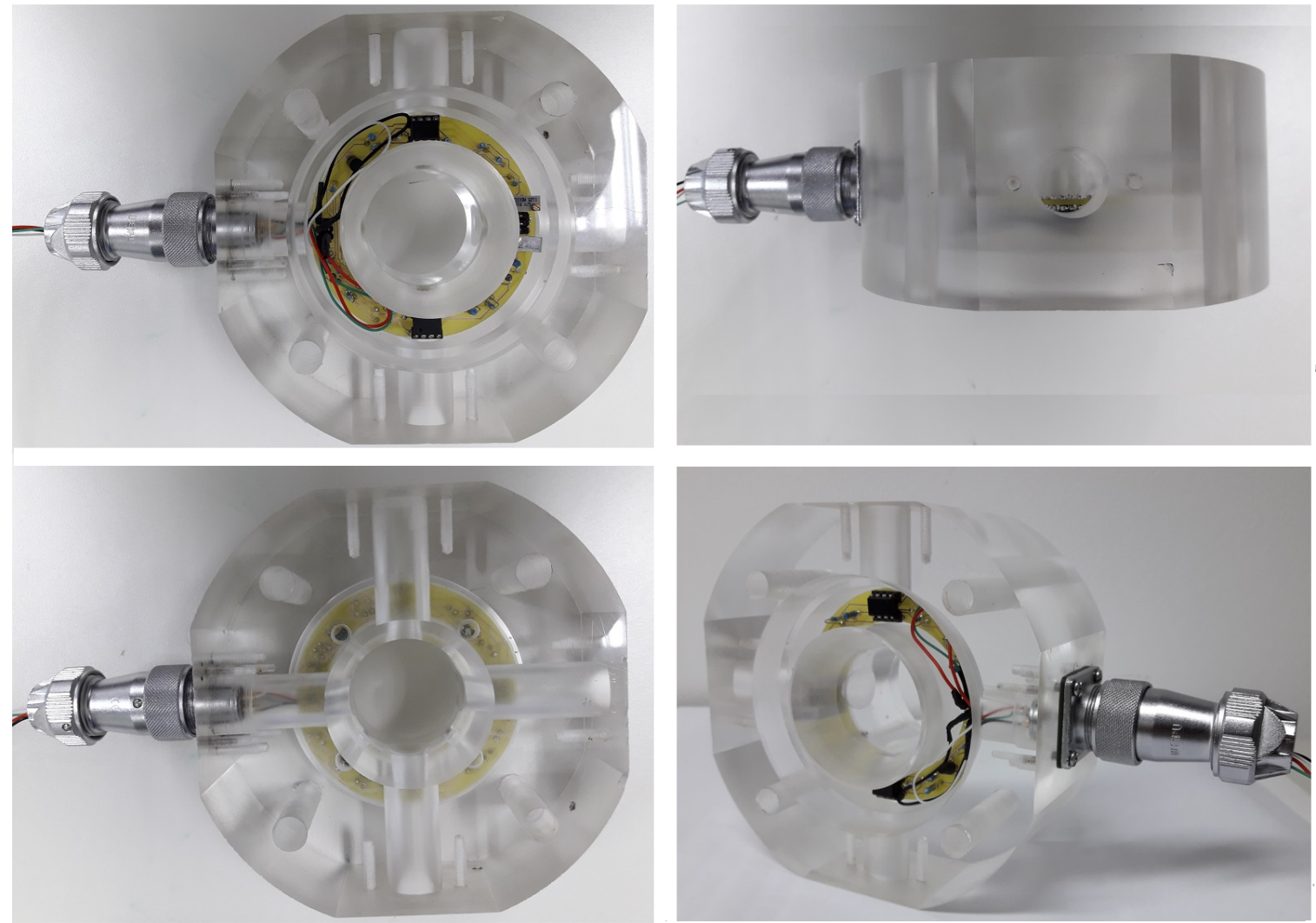

Figura 34: Vista superior, direita, inferior e isométrica da montam final

Nesta versão automática do SIREA, serão instalados 4 contadores idênticos. Um tem a função de estimar as velocidades das esferas injetadas no trocador de calor. Os outros dois, instalados com uma distância de $5 \mathrm{~cm}$ entre os feixes infravermelhos, têm a função de estimar as velocidades de retorno das esferas, após percorrerem o trocador de calor, e também a vazão de retorno da água de limpeza. O quarto contador foi instalado entre as câmaras de injeção e recuperação de esferas, para indicar o número total de esferas transpostas. 


\section{Projeto de Automação}

A nova configuração do SIREA tem como grande mudança o fato de que a configuração em circuito fechado fica apenas em relação às esferas, ou seja, a água passa a circular em circuito aberto. Esta mudança foi feita para evitar um acúmulo maior de sujeira, proveniente dos diversos ciclos de operação, na parte interna do SIREA, criando dificuldades para o contador de esferas.

A Figura 35 ilustra, de forma esquemática essa nova concepção do SIREA.

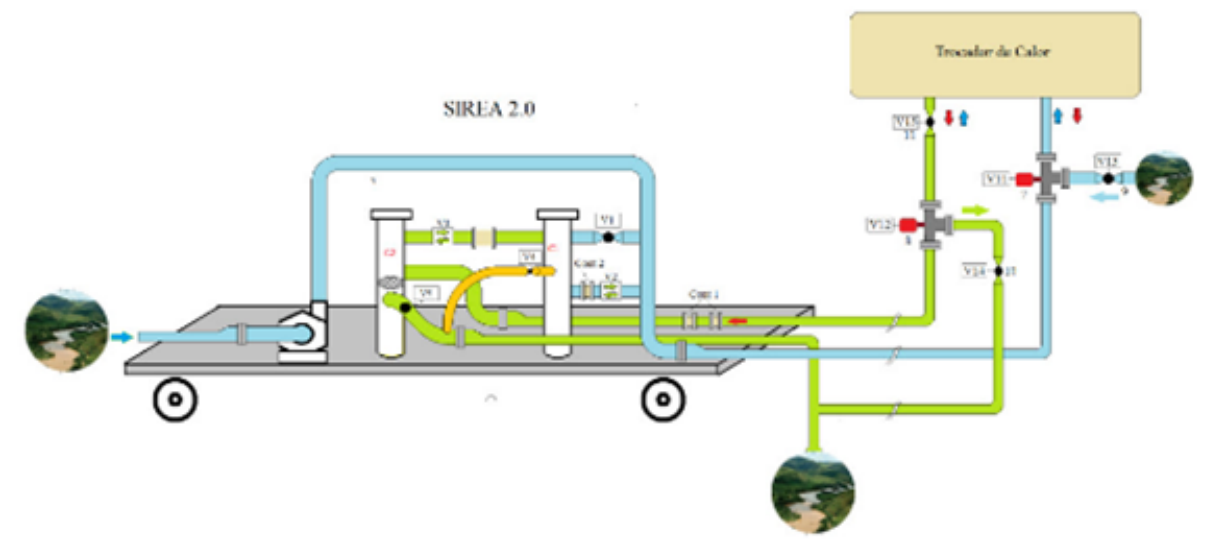

Figura 35: SIREA Versão 2.0 acoplado ao trocador de calor.

A alternativa tecnológica proposta mostra-se bastante conveniente, pois o SIREA passa a operar com água limpa (bombeada diretamente do anel da água de resfriamento), a cada ciclo de limpeza. A água que deixa o trocador (carregando as esferas que acabaram de circular para remover o fouling) é descartada no ramal de descarga da água de circulação, retornando ao canal de fuga das turbinas. Filtros (separadores de esferas) instalados no SIREA asseguram a recuperação das esferas antes da descarga da água no canal de fuga [5]. Na Figura 36 observa-se o esquema dos elementos da automação da versão 2.0 do SIREA.

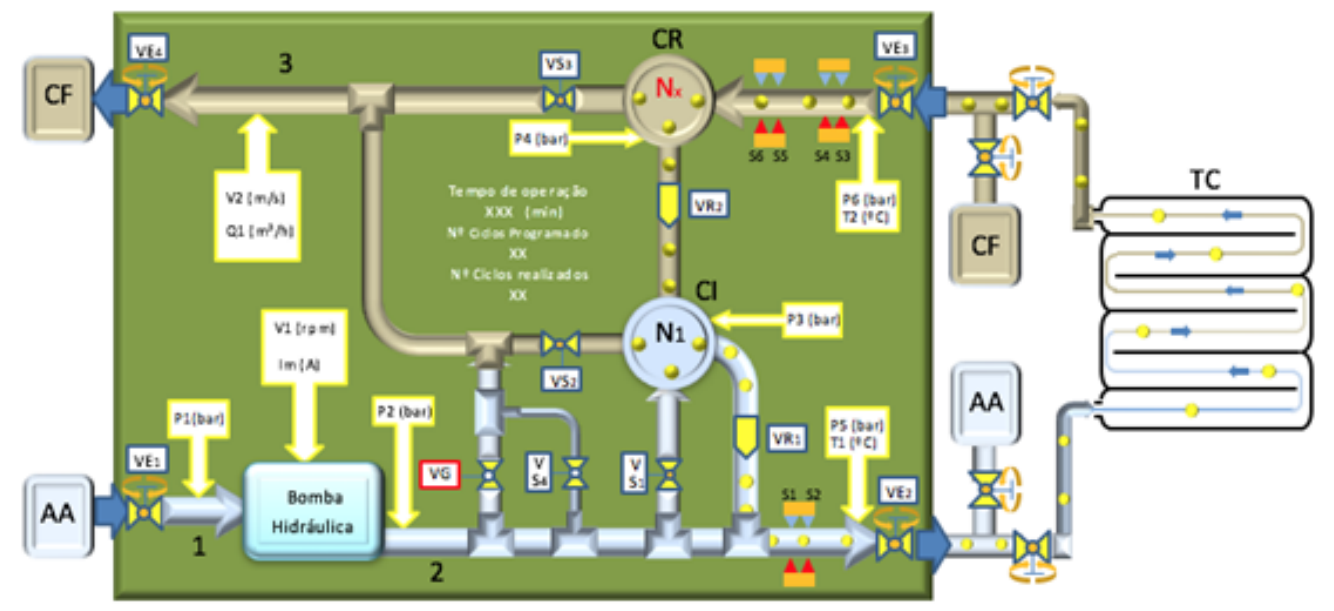


LEGENDA DOS COMPONENTES:

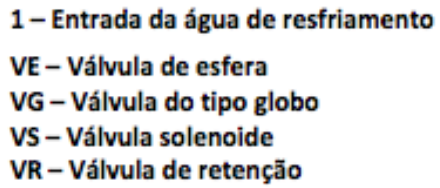

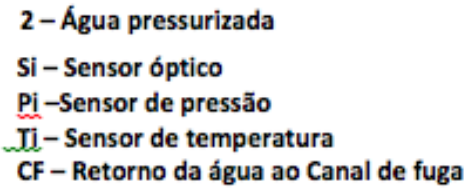

3 - Retorno da água (canal de fuga) após limpeza do TC

Cl - Câmara de Injeção de esferas abrasivas

CR - Câmara de Recuperação de esferas abrasivas

TC - Trocador de Calor submetido à limpeza

AA - Anel de água de resfriamento

Figura 36: Esquema da nova concepção do SIREA.

Conforme pode ser observado na Figura 36, nessa versão 2.0 do SIREA, foi interrompida a conexão entre a entrada da bomba e o retorno da câmara de recuperação das esferas. Essa é uma bomba hidráulica acoplada a um motor elétrico (grupo bomba-motor: Modelo KSB 32-200, Motor de 20 CV, altura manométrica de 50 metros de coluna de água e vazão de $40 \mathrm{~m} 3 / \mathrm{h}$ ). Tão logo essas adaptações sejam concluídas e o sistema de automação instalado, a versão 2.0 do SIREA será testada em ambiente laboratorial, antes de sua transferência para a usina, quando deverá ser acoplado ao grupo gerador para ser submetido a um ensaio de funcionalidade [5].

A empresa CETEM Automação Industrial Ltda. foi contratada para realizar a implementação da automação do SIREA. Este desenvolvimento contempla software, animação e projeto elétrico. Conforme dito no item 2.3, para a implementação da automação é necessário um processo de controle. Este processo é composto por "pontos", que são os elementos controlados e monitorados pertencentes ao processo. A seguir apresentam-se os principais elementos da automação do projeto.

Para implementar o SIREA, foi desenvolvido um programa de supervisão e controle por meio do software Indusoft, que permite um controle dos sensores, medidores de pressão e de vazão, solenoides e da quantidade de esferas, assim é possível ter um total controle do comportamento do sistema em geral. Para essa implementação, foi desenvolvida uma programação no CLP Mitsubishi modelo FX5U-32MR/ES.

\subsection{Programação do CLP}

A linguagem utilizada no SIREA foi Ladder, e é utilizada de forma estruturada em variáveis. Das linguagens textuais, esta é bastante recomendada para aplicações complexas que envolvam a descrição de comportamento sequencial.

Para a programação são criadas Tags, que são nomes dados aos endereços das variáveis físicas do sistema.

\section{Início}

Abaixo, são apresentadas as condições iniciais para que se inicie o processo de injeção de esferas que são:

i. Quando há o input de start do sistema, utilizando a chave de início "bCarregar", ilustrada na figura 37.

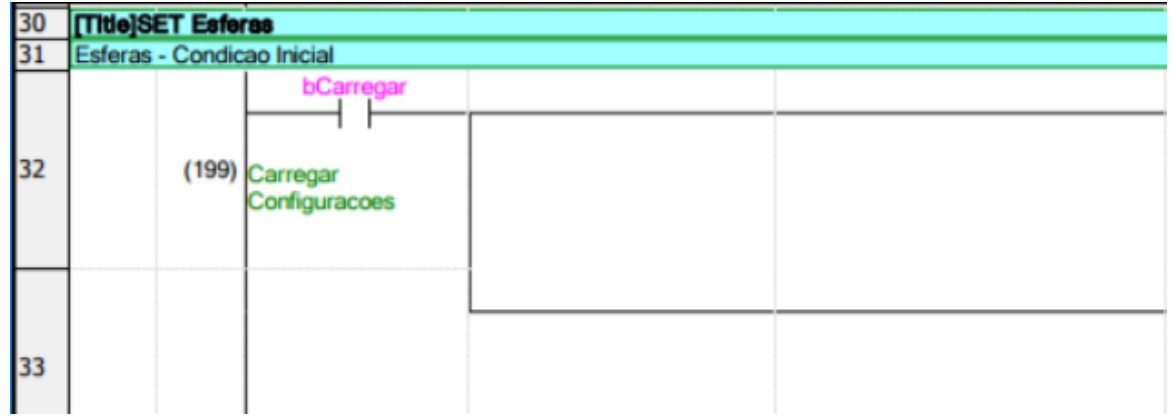

Figura 37: Início do processo de injeção. 
ii. Quando há esferas na câmara de injeção: o bloco de função "MOV", mostrado na figura 38, recebe o número de esferas que serão usadas no ciclo que será iniciado e armazena na TAG "nEsfera".

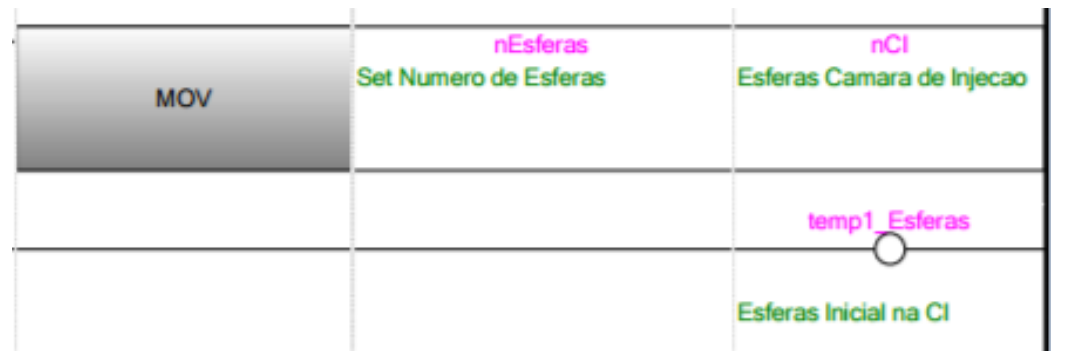

Figura 38: Carregamento do número de esferas a serem usadas.

Após isso, o programa verifica se há essas esferas na câmara de injeção, variável que tem o nome de "nCI", como ilustrado na figura 39.

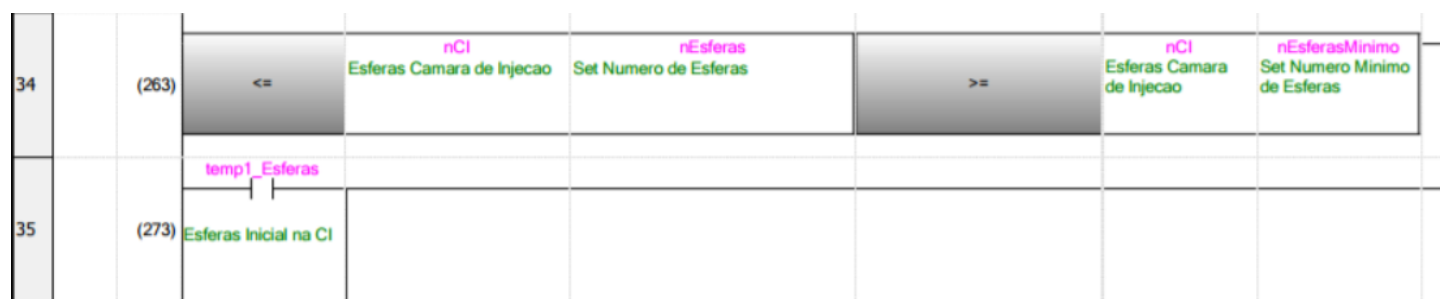

Figura 39: Verificação do número de esferas disponíveis.

iii. Outra condição para que se inicie o processo é se o tamanho da esfera está correto, entre os limites aceitáveis, representados por "nTamMedio" e "nTamMinimo" ilustrado na figura 40;

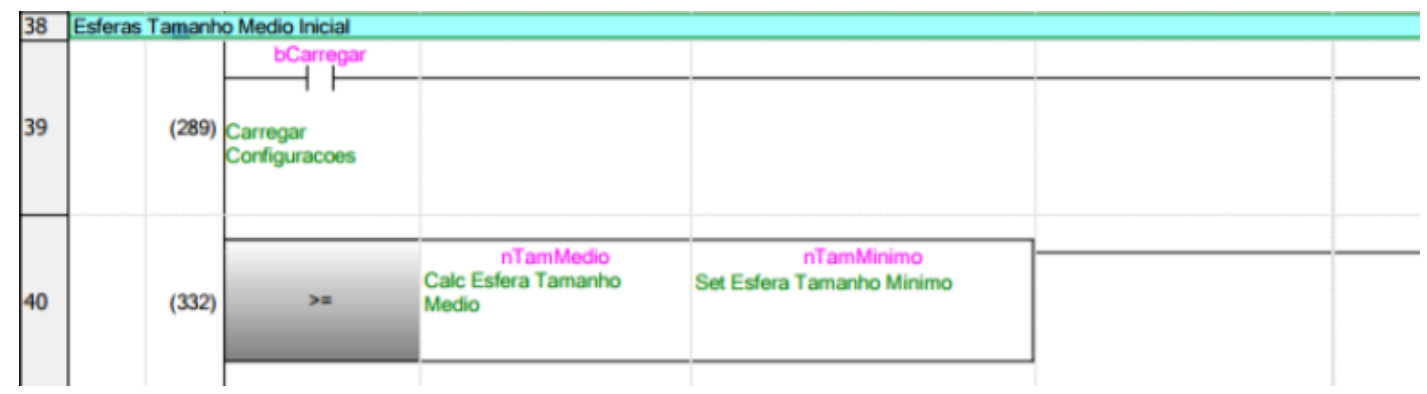

Figura 40: Condição de tamanho da esfera.

iv. A última condição para o início, é se há ciclos a serem cumpridos (quantidade de ciclos determinada pelo operador), representados pela tag "nCiclosProgramados". Conforme ocorre o término de um ciclo, "nCiclosRealizados" é incrementada, até que esta chegue ao valor que "nCiclosProgramados" tinha inicialmente. Finalmente após as 4 condições serem cumpridas, as Tags de cada condição, representadas respectivamente por "START", "EsferasCI", "TamanhoOK" e "ciclo", estarão de acordo para iniciar o processo de injeção de esferas, representado pela tag "bIniciar", como visto na figura 41. 


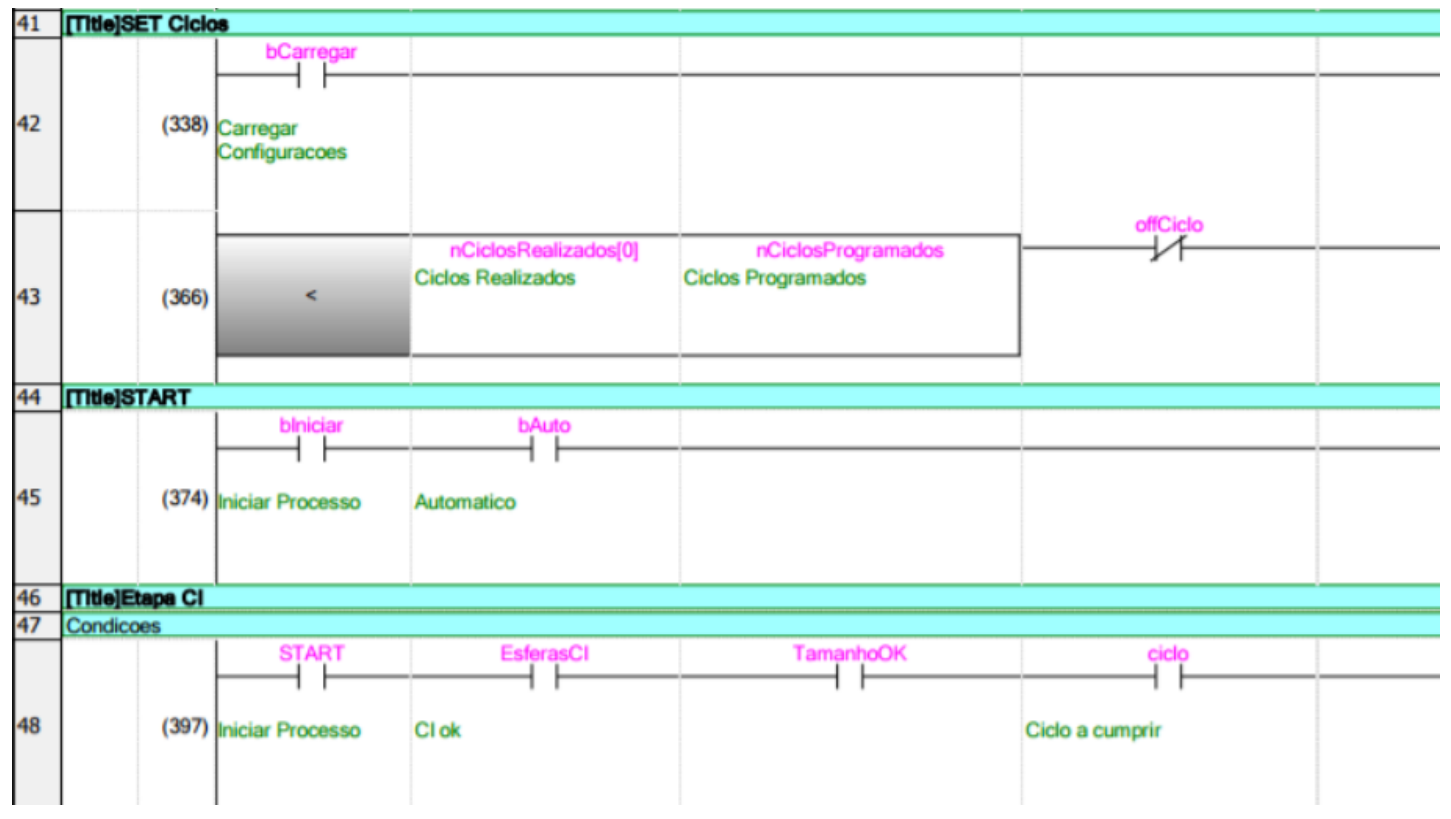

Figura 41: Condição de que ainda há ciclos a serem cumpridos.

\section{Término}

A figura 42 mostra quando termina a injeção de esferas no sistema:

i. Ao passarem pelo sensor 1, representado pela Tag "bS1", as esferas vão decrementando a câmara de injeção. Logo em seguida, ao passarem pelo sensor 3 vão incrementando na câmara de recuperação.

Quando a última esfera passar pelo sensor 3, "bS3", este aciona o contador, ou seja, após passagem da última esfera o contador não recebe mais sinal, então é encerrado o processo.

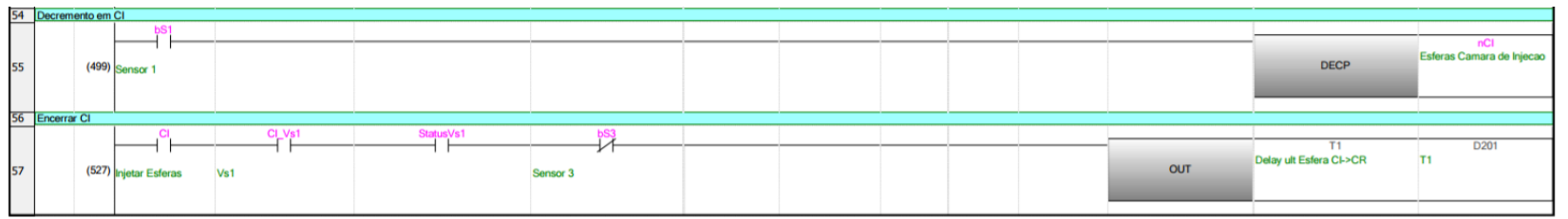

Figura 42: Fim do processo de injeção de esferas.

A figura 43 ilustra o bloco do conversor A/D, "rInversorHz". Alguns sensores e comandos ligados nas entradas dos CLPs são digitais, outros tem saída analógicas (termopares, potenciômetros, etc). Nesses casos, o CLP tem entradas específicas para sinais analógicos, e que sofrem uma conversão A/D internamente.

Um sinal analógico proveniente de um medidor de pressão, por exemplo, que varia de 0 a 10 bar precisa ser convertido em sinal digitalizado, que é o tipo de sinal que a CPU, representado por "SD6180", "consegue" ler. Então na entrada do CLP 0 bar será $4 \mathrm{~mA}$, e 10 bar será $20 \mathrm{~mA}$. 


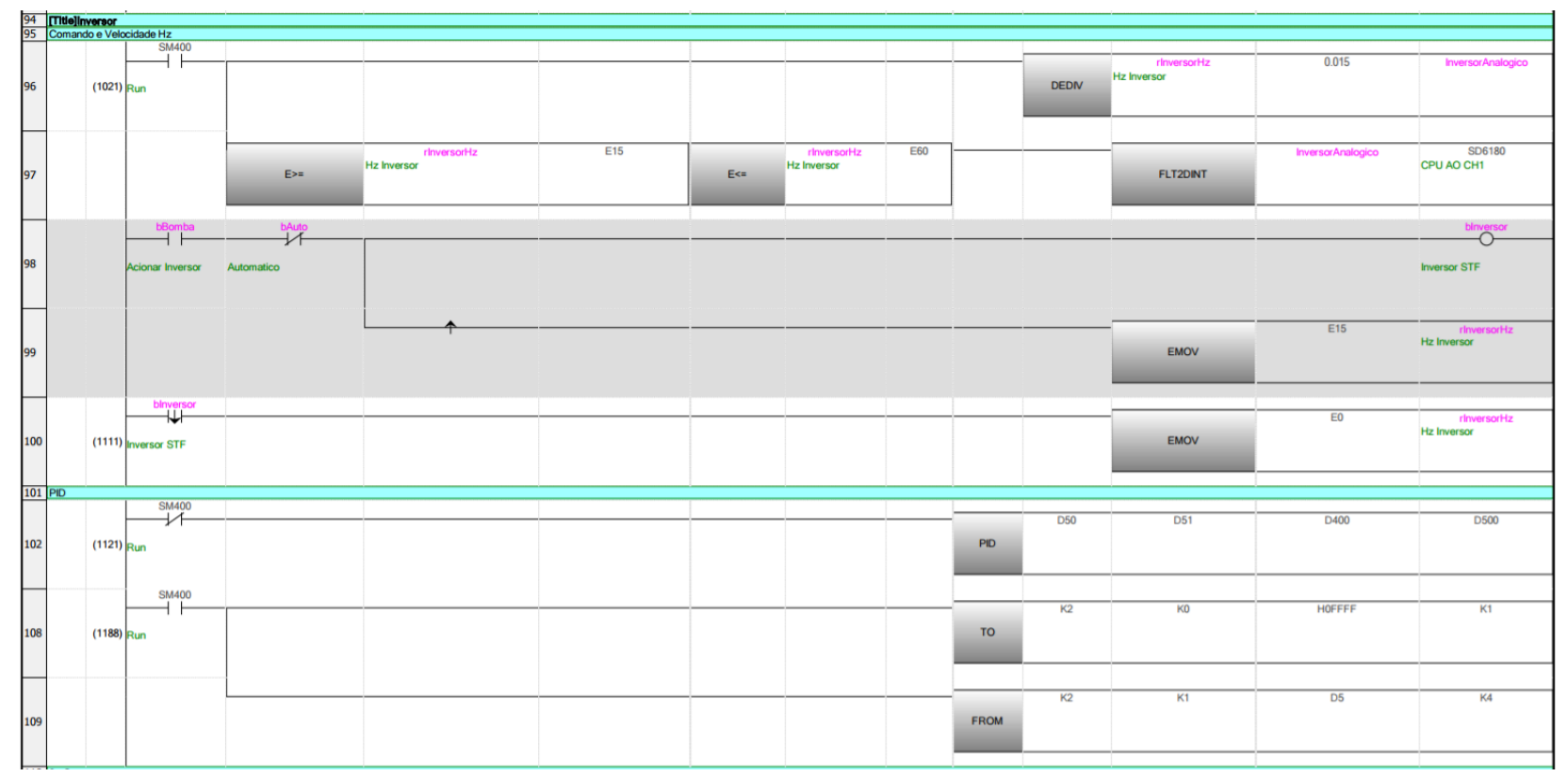

Figura 43: Bloco do inversor A/D.

\subsection{Programação SCADA}

O sistema de supervisão apresentado a seguir foi criado com base nos requisitos do projeto SIREA.

\section{a) Tela de Visão Geral}

A tela inicial, representada pela figura 44, mostra uma visão geral do projeto. É possível observar um controle de todos os instrumentos, como se uma válvula está aberta ou fechada, controle de esferas injetadas e recebidas pelo sistema, controle da temperatura nos trocadores de calor.

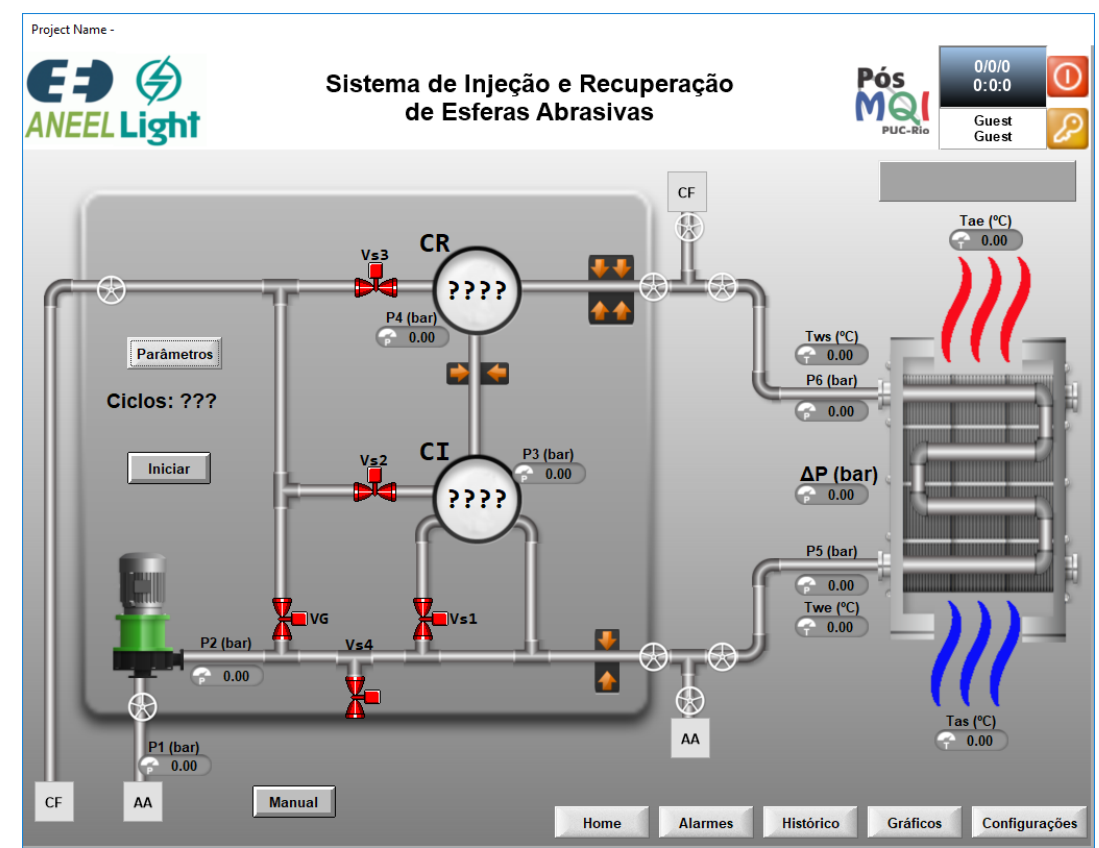

Figura 44: Tela de Visão Geral. 
O operador inicia o processo de injeção de esferas que chegarão aos trocadores de calor.

\section{b) Configuração de parâmetros}

Nas telas de configurações dos parâmetros é possível uma identificação de cada trocador de calor que receberá as esferas para a limpeza, como ilustrado na figura 45.

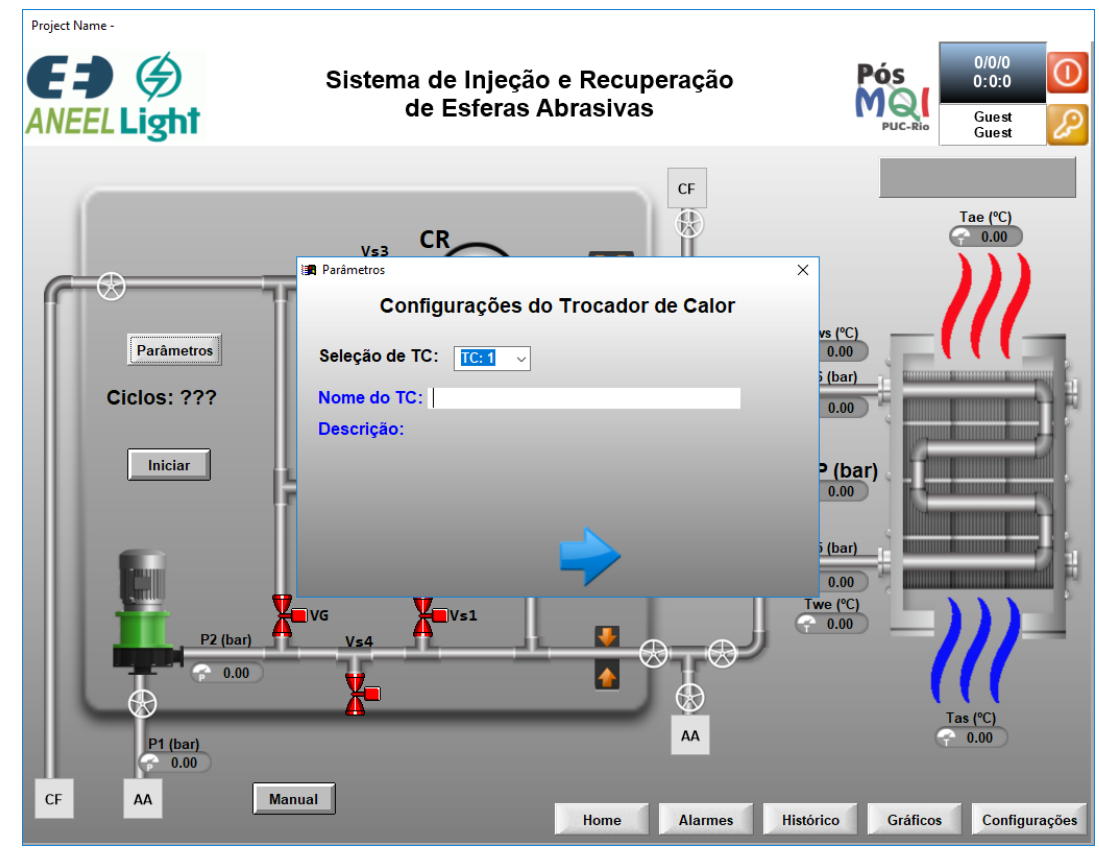

Figura 45: Tela de identificação dos trocadores de calor.

É possível configurar também parâmetros como: números de esferas que serão injetadas, dimensão das mesmas e também números de ciclos de limpeza que ocorrerão, como mostra a figura 46.

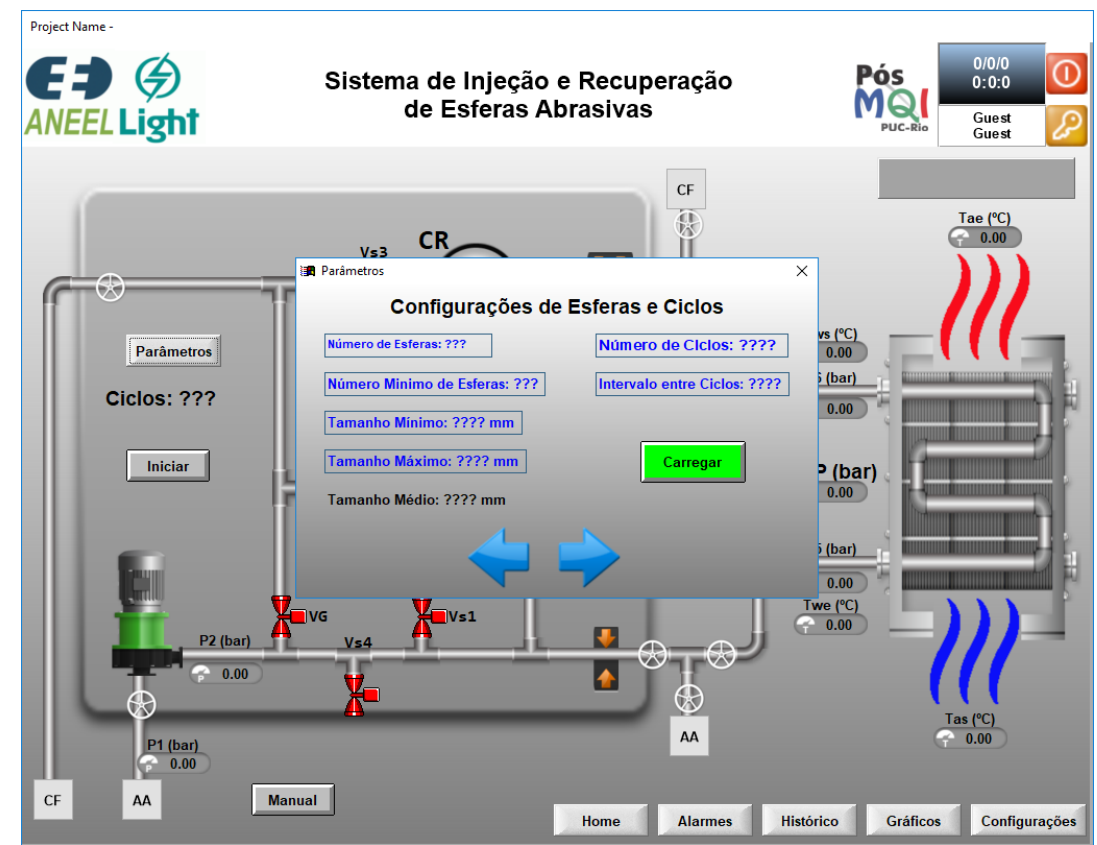

Figura 46: Tela de configuração de esferas e ciclos. 
E ainda em configuração de parâmetros, é possível configurar, de acordo com as especificações, os limites de pressão e temperatura da água, como mostra a figura 47.

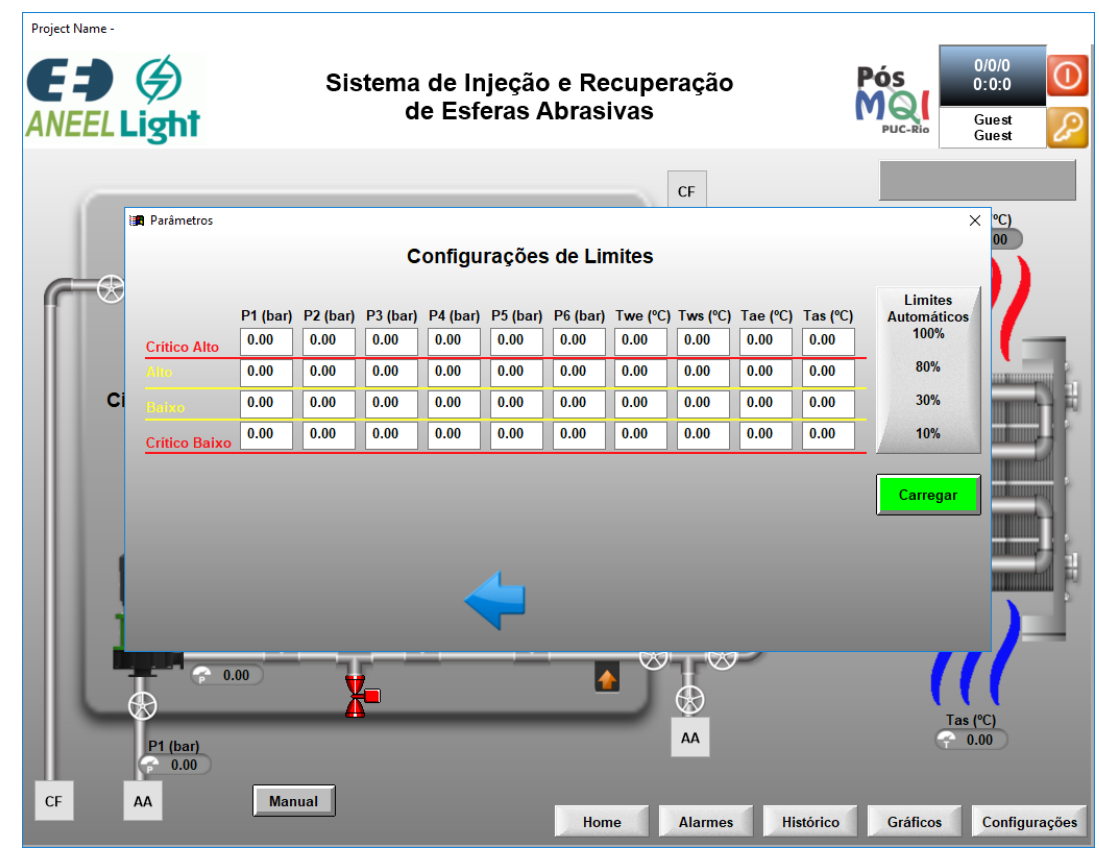

Figura 47: Tela de configuração de limites.

Como visto na figura 47, existem 4 tipos de limites possíveis de serem atingidos:

- Baixo: representa 30\% da temperatura ou pressão máxima da água aceitável para o instante da operação;

- Baixo Crítico: representa $10 \%$ da temperatura ou pressão máxima da água aceitável para o instante da operação;

- Alto: representa $80 \%$ da temperatura ou pressão máxima da água aceitável para o instante da operação;

- Alto Crítico: 100\% da temperatura ou pressão máxima da água aceitável para o instante da operação;

\section{c) Tela de Reconhecimento de Alarmes}

Ao serem atingidos esses limites, alarmes serão exibidos na tela de controle. Alarmes baixo e alto animarão com a cor amarela, e alarmes baixo crítico e alto crítico animarão com a cor vermelha. No momento em que algum alarme for exibido, o operador deverá "reconhecer" o alarme na tela mostrada pela figura 48. Através desse reconhecimento o operador se torna responsável por tomar uma decisão quanto a essa notificação. 


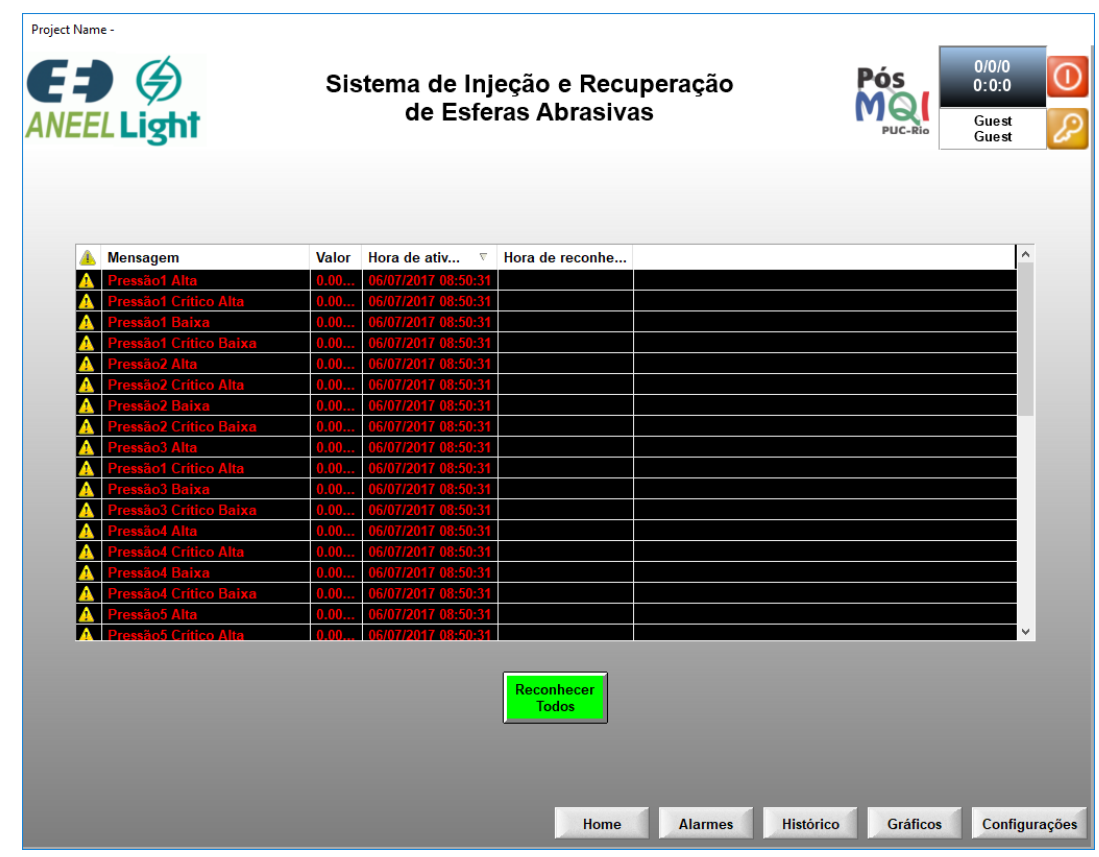

Figura 48: Tela de Reconhecimento de alarmes.

\section{d) Tela de Análise de Resultados}

Conforme visto na figura 49, após um ciclo é possível gerar gráficos do comportamento de parâmetros como temperatura e pressão, variando com o tempo. Esses gráficos são muito importantes para relatórios de controle do processo em geral.

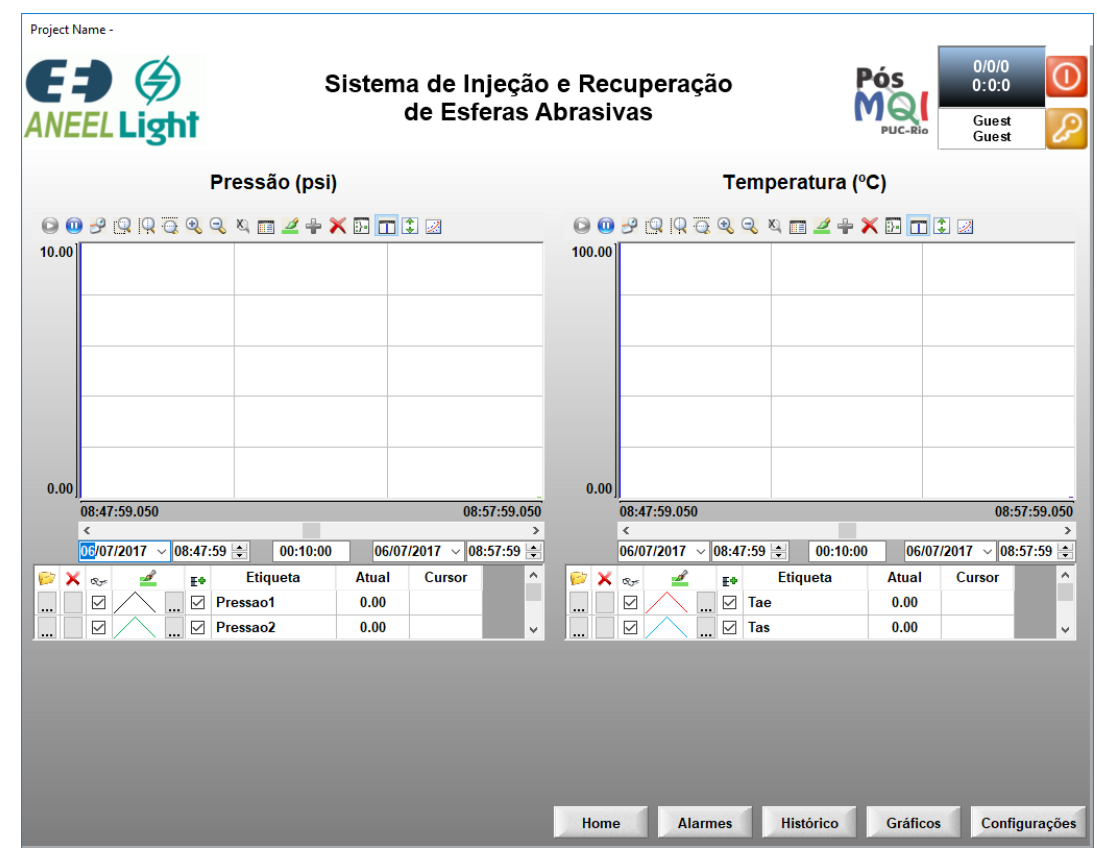

Figura 49: Gráficos do comportamento. 


\subsection{Comunicação CLP-SCADA}

A comunicação entre o software Indusoft e os outros elementos é feita por dois protocolos: Modbus TCP e Ethernet TCP.

A comunicação Ethernet trabalha enviando dados na rede e detectando colisões de pacotes. O Padrão Ethernet também define o meio físico de conexão do cabeamento. Além disso, a comunicação Ethernet permite diversos Protocolos dentro do Padrão.

O protocolo Modbus é do tipo cliente-servidor / mestre-escravo, muito usado para monitorar e programar dispositivos como: IHM, PCs, comunicação com instrumentos [7]. Só ocorre de fato a comunicação no meio físico quando for solicitado pelo mestre. Para trabalhar o Protocolo Modbus em redes Ethernet, os dados são encapsulados em TCP (Transmission Control Protocol - Protocolo de Controle e Transmissão), sendo esses dados encapsulados chamados de frames, que contêm as seguintes informações: o endereço do escravo, o comando a ser executado, a quantidade de variáveis de dados e uma verificação de consistência dessas variáveis. 


\section{Testes e Conclusões}

Este projeto contribuiu para o desenvolvimento do Projeto de P\&D Light/Aneel Ref.: 0010/2016, em andamento. Mais especificamente, contribuiu para a etapa de automação da alternativa tecnológica do sistema de limpeza de trocador de calor, que faz uso de esferas abrasivas, para viabilizar a limpeza sem a necessidade de paradas técnicas que implicam na interrupção da geração.

Automação industrial é um tema de grande abrangência, com potencial de aplicação em qualquer área industrial. Analisando os sistemas de limpeza de trocadores de calor da Usina Fonte Novas, onde suas operações ainda são manuais, a automação do projeto de $\mathrm{P} \& \mathrm{D}$, que propõe a construção de alternativa tecnológica (SIREA) de limpeza, mostrou-se extremamente eficaz pois, além dos benefícios gerados pelos ganhos de eficiência, produz benefícios econômicos já que evita a parada das turbinas durante o processo de limpeza.

Conforme documentado na seção 4.2, "Programação SCADA", é possível observar os benefícios do projeto. Os subsistemas de supervisão e controle introduzidos, concebidos para comandar a etapa de manipulação, agrega vantagens ao processo como um todo, dentre essas: permite maior controle sobre do processo de limpeza; viabiliza o monitoramento em tempo real de possíveis falhas online; permite análise estatística dos ciclos de limpeza e resulta em menor desperdício de tempo para o processo.

O equipamento automatizado do SIREA foi testado e validado em ambiente laboratorial, mostrando-se capaz de gerar os sinais lógicos que comandam as operações da automação de forma automática, gerando, também, um log de todas as operações de funcionamento realizadas. Embora testado em laboratório, o sistema aguarda para ser validado no ambiente industrial, da usina Fontes Nova, tão logo a usina consiga realizar uma parada técnica de manutenção para permitir a completa instalação do sistema de limpeza proposto. 


\section{Referência Bibliográficas}

[1] V.H. Oliveira JR. Validação metrológica de alternativa tecnológica para mitigação de incrustação em trocadores de calor. 2015. Dissertação (Mestrado em Metrologia) - Pontifícia Universidade Católica do Rio de Janeiro. (Orientador: M.N. Frota).

[2] A.V. Neves. Mitigação de incrustação em trocadores de calor de hidrogeradores: estudo do caso da Usina Fontes Nova. 2013. Dissertação (Mestrado em Programa de Pós-Graduação em Metrologia) Pontifícia Universidade Católica do Rio de Janeiro, Pontifícia Universidade Católica do Rio de Janeiro. (Orientador: M.N. Frota).

[3] O. K Carvalho. Projeto e desenvolvimento de um sistema optoeletrônico para contagem automática de esferas abrasivas mitigadoras de incrustação em trocadores de calor. Projeto de Graduação em Automação, PUC-RIO, Rio de Janeiro, junho de 2016. (Trabalho orienta-do pelos Prof. Carlos Roberto Hall Barbosa e Maurício N. Frota).

[4] S.B. Lubicz. Projeto e desenvolvimento de sistema opto-eletrônico para contagem de esferas abrasivas em meios turvos. Projeto de Graduação em Engenharia Mecânica, PUC-RIO, Rio de Janeiro, Dezembro de 2016. (Trabalho orientado pelos Prof. C.R.H. Barbosa e M.N. Frota).

[5] PósMQI/PUC-Rio, Documento interno. Relatório Parcial \#5 (elaborado pela PUC-Rio) de desenvolvimento do projeto de P\&D Light/Aneel Projeto de P\&D referência 5161-0010/2016, intitulado: Cabeça de Série de um sistema inovador de limpeza de trocadores de calor de hidrogeradores, em desenvolvimento pelo Programa de Pós-Graduação em Metrologia da PUC-Rio, no âmbito do Programa Pesquisa e Desenvolvimento do Setor Elétrico (Lei no. 9.991, de 24/07/2000, Resolução Aneel 271, de 19/07/2000), objeto de contrato (no. 4500.36.2039) celebrado entre Light Energia S/A (Usina Fontes Nova, Piraí, RJ) e Faculdades Católicas (PUC-Rio) em set/2016.

[6] PósMQI/PUC-Rio, Documento interno. Relatório Parcial \#4 (Mês 1, Etapas 1 e 2), elaborado pela PUC-Rio, de desenvolvimento do projeto de P\&D Light/Aneel Projeto de P\&D referência 51610010/2016, intitulado: Cabeça de Série de um sistema inovador de limpeza de trocadores de calor de hidrogeradores, em desenvolvimento pelo Programa de Pós-Graduação em Metrologia da PUC-Rio, no âmbito do Programa Pesquisa e Desenvolvimento do Setor Elétrico (Lei no. 9.991, de 24/07/2000, Resolução Aneel 271, de 19/07/2000), objeto de contrato (no. 4500.36.2039) celebrado entre Light Energia S/A (Usina Fontes Nova, Piraí, RJ) e Faculdades Católicas (PUC-Rio) em set/2016. 